Studies in African Linguistics

Volume 41, Number 1, 2012

\title{
NOTES ON GWAMA GRAMMAR ${ }^{1}$
}

\author{
Dirk Kievit \& Erika Robertson \\ SIL Ethiopia
}

\begin{abstract}
Based on original field work, the paper provides a preliminary characterization of the grammar of Gwama, a little-researched Nilo-Saharan language of western Ethiopia belonging to the Koman language cluster. Following a brief overview of the phonology, the article covers the major word classes and structures of the language. Special attention is given to the structure of nouns and verbs, including converbs. The article makes a unique contribution to the study of Gwama in that most of the analysis is based on collected elicited texts. Occasional references are made to discourse features. Copious examples from texts illustrate the grammatical points throughout the article. Two sample texts appear in an appendix.
\end{abstract}

\section{Introduction}

This paper focuses on the main points of the morphology and syntax of Gwama with a few brief comments on the phonology. Based primarily on a set of texts collected

\footnotetext{
${ }^{1}$ The research presented here was conducted by Erika Robertson in partnership with the Bureau of Culture, Sport, and Tourism of the Benishangul-Gumuz Regional Administration of Ethiopia. It was carried out primarily in Asosa between February and September 2006 with the help of language assistants from Keser, Tongo, and Zebsher. The data is supplemented with data collected by Mike Bryant in December 2004. Dirk Kievit was responsible for the write-up of the data. We would like to thank Ato Gida Maram, Ato Hangug Wedesa, Ato Mamut Madali, and Ato Tolina Nitar for working as language assistants, and Ato Melese Mihretu for his assistance as translator. Further thanks are due to Dianne Friesen for her assistance as consultant in the project and to Colleen Ahland, Gerrit Dimmendaal, AnneChristie Hellenthal, Don Killian, Constance Kutsch Lojenga as well as the reviewers from SAL for commenting on earlier versions of the paper. Any remaining deficiencies in the paper are entirely the authors' responsibilities.
} 
during field work in 2004 and 2006, the paper complements Zelealem (2005), which is a more detailed grammatical description but possibly of a different variety of the language here described. Besides elicited texts, the present study is also based on elicited sentences, word lists, and grammatical paradigms.

The primary texts on which this study is based are twenty-four brief texts by a number of native speakers of Gwama mostly from Keser and some from Zebsher. Siebert, Siebert, and Wedekind (2002:10) report that "Zebshir [Zebsher] is considered a village of high prestige" among the Gwama. In addition, three texts by non-native speakers of Gwama whose first language was Komo were also used (but not relied on to the same extent as the other texts).

As mentioned in Siebert and Bryant (2007:461), confusion abounds about the language names and classification surrounding Gwama. Zelealem (2005) does not indicate the home towns of the informants for his data and in some waysparticularly in the description of the verb - the data there presented is quite different from the data described here. The discrepancy between the two studies may be due to dialectical differences.

A preliminary paper such as this cannot hope to describe the grammar exhaustively. It is hoped that others will continue to research this little-known language and benefit from the research presented here.

\section{Language and people}

Gwama (more commonly known in the literature as Kwama) is a Nilo-Saharan language and one of five Koman languages belonging to the Komuz group, the others being Gule and Komo in Sudan, and Opo and Uduk in Ethiopia (Lewis 2009). It is spoken by several thousand speakers in western Ethiopia, with additional speakers living across the border in Sudan. The Gwama people are subsistence farmers. Culturally, they are considered part of the Mao people. Intermarriage between the Gwama and the Komo is common. In Ethiopia, the Komo tend also to speak Gwama but the Gwama do not tend to speak Komo; the reverse is said to be true in Sudan. Gwama does not appear to be imminently endangered (A. Joswig, pers. comm.). Language development efforts are promising for the future vitality of the language; in fact, the Gwama are reported to have "a very positive attitude" towards their own language (Siebert, Siebert, and Wedekind 2002:13). 


\section{Notes on phonology}

Table 1 provides an inventory of the 21 consonant phonemes in Gwama. Note especially the presence of ejectives.

Table 1. Inventory of consonant phonemes in Gwama.

\begin{tabular}{|c|c|c|c|c|c|c|c|}
\hline \multicolumn{2}{|c|}{ Manner of articulation } & $\begin{array}{l}\text { Bi- } \\
\text { labial }\end{array}$ & $\begin{array}{l}\text { Alveo- } \\
\text { lar }\end{array}$ & $\begin{array}{l}\text { Post } \\
\text { alveolar }\end{array}$ & Palatal & Velar & Glottal \\
\hline \multirow{2}{*}{ Plosives } & $\mathrm{Vl}$ & $/ \mathrm{p} /$ & $/ \mathrm{t} /$ & & & $/ \mathrm{k} /$ & \\
\hline & $\mathrm{Vd}$ & $/ \mathrm{b} /$ & $/ \mathrm{d} /$ & & & /g/ & \\
\hline Ejectives & & $/ \mathrm{p}^{\prime} /$ & $\begin{array}{l}/ \mathrm{t} \prime \\
/ \mathrm{s} \prime\end{array}$ & & & $/ \mathrm{k}^{\prime} /$ & \\
\hline \multirow{2}{*}{ Fricatives } & $\mathrm{Vl}$ & & $/ \mathrm{s} /$ & $\mid \mathrm{g} /$ & & & $/ \mathrm{h} /$ \\
\hline & $\mathrm{Vd}$ & & $|z|$ & & & & \\
\hline Nasals & & $/ \mathrm{m} /$ & $/ \mathrm{n} /$ & & & $/ \mathrm{y} /$ & \\
\hline $\begin{array}{l}\text { Lateral } \\
\text { approximant }\end{array}$ & & & $/ 1 /$ & & & & \\
\hline Trill & & & $/ \mathrm{r} /$ & & & & \\
\hline \multirow{2}{*}{$\begin{array}{l}\text { Central } \\
\text { approximants }\end{array}$} & $\begin{array}{l}\text { Un- } \\
\text { rnd }\end{array}$ & & & & $/ \mathrm{y} /$ & & \\
\hline & Rnd & & & & & $/ \mathrm{w} /$ & \\
\hline
\end{tabular}

Contrary to Bender (1983:285), a recent study by Hellenthal and Kutsch Lojenga (2011) found Gwama to have seven basic vowel phonemes, five [-ATR] and two [+ATR]. The former set consists of $/ \mathrm{I} /, / \varepsilon /, / \mho /, / \mathrm{J} /$, and $/ \mathrm{a} /$, while the latter set consists of $/ \mathrm{i} /$ and $/ \mathrm{u} /$. ATR vowel harmony is found in verbal morphology, and vowel length is predictable.

Moreover, contrary to Wedekind and Wedekind (2002:10), which posits two contrastive tones, Hellenthal and Kutsch Lojenga (2011) discovered three contrastive level tones (High, Mid, and Low), as well as a rising and a falling tone. ${ }^{2}$ Minimal

${ }^{2}$ In the present paper, tone is marked as either Low or High, as transcribed when the data was collected. In light of Hellenthal and Kutsch Lojenga (2011), tone will need to be rechecked for the data presented here. Words that are unmarked for tone in the present paper should not 
pairs in Table 2 show the importance of lexical tone (Mid tone is unmarked in this table).

Table 2. Lexical tone.

\begin{tabular}{|l|l|l|l|l|l|l|}
\hline \multicolumn{2}{|c|}{ mono-syllabic words } & & \multicolumn{3}{|l|}{ disyllabic nouns } \\
\hline H & pák & 'shoes' & & HH & t'áfá & 'mushroom' \\
\hline M & wal & 'child' & & MH & tak'Í & 'saliva' \\
\hline L & tàm & 'honey' & & LH & kàká & 'grandmother' \\
\hline R & măn & 'children' & & RH & tăyá & 'bamboo' \\
\hline
\end{tabular}

\section{Pronouns and pronominal affixes}

Table 3 shows the free pronouns as well as the verbal pronominal affixes. (Tone is not marked in this table as it is not yet clear at this point what the underlying tone is for each form.) Note the gender distinction in $3 \mathrm{SG}^{3}$ and the inclusive versus exclusive distinction in 1PL - two features that are said to be common in Koman languages but rare in other Nilo-Saharan languages (Bender 2007:418). Possibly there is a 3SG neuter form as well, as in Komo (Burns 1947:14), but this requires further investigation.

be interpreted as being Mid (as in Hellenthal and Kutsch Lojenga 2011) but rather as not being transcribed fully. Rather than leaving tone entirely unmarked, as is done in Zelealem (2005) (with the exception of the wordlist), we hope that the tone marked as it is - though imperfect - will serve as a starting point for future researchers of Gwama.

${ }^{3}$ See list of abbreviations in the appendix. 
Table 3. Pronouns and pronominal affixes.

\begin{tabular}{|c|c|c|c|c|c|c|}
\hline \multirow[b]{2}{*}{ Person } & \multicolumn{2}{|l|}{ Pronouns } & \multicolumn{4}{|c|}{ Subject pronominal affixes } \\
\hline & SBJ, OBJ & POSS & IPFV & PFV & NEG & PASS \\
\hline $1 \mathrm{SG}$ & ga & na & na- & - ni & $-g a$ & -ba \\
\hline $2 \mathrm{SG}$ & $\mathrm{ik}$ & $\mathrm{k} \varepsilon$ & ga- & -gi & -bi & -bi \\
\hline $3 \mathrm{MSG}$ & uhay & $\mathrm{d} \varepsilon$ & na- & - ni & -bi & $-b \varepsilon$ \\
\hline $3 \mathrm{FSG}$ & hap & dap & a- & $-\mathrm{a}$ & $-b a b$ & $-b a b$ \\
\hline 1PL.EXCL & $\mathrm{ma}$ & $\mathrm{ma}$ & ma- & $-m \varepsilon$ & $-\mathrm{ma}$ & -ba \\
\hline 1PL.INCL & 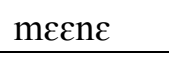 & mecne & na- & $-\mathrm{n} \varepsilon$ & $-m \varepsilon$ & -ba \\
\hline 2PL & um & kom & mi- & $-m \varepsilon$ & -bum & -ba \\
\hline 3PL & hun & bun & bi- & $-b \varepsilon$ & -bun & $\begin{array}{l}\text {-bun, } \\
\text {-bugun }\end{array}$ \\
\hline
\end{tabular}

Many alternate forms of the pronouns and pronominal affixes presented above are attested in the data, particularly in terms of the vowels. Some - perhaps most - of these variants may be phonologically conditioned (in terms of vowel harmony or contrast) while other variants may be due to interaction with other, not yet fully analyzed, environments. Verb morphology, including pronominal affixation, remains, therefore, a particularly important area requiring further study and analysis.

4.1 Free pronouns. (a) Subject and object. Since the subject may be marked on the verb by a pronominal affix, free subject pronouns are not required in Gwama and, for this reason, are seldom encountered in the texts elicited for the present study. However, example (1) illustrates the use of an emphatic subject pronoun in the opening line of a text on Gwama culture. 

(1) bilte
ma
gwama $k^{\mathrm{w} e}$-me
siyana
until.now 1PL.EXCL.SBJ Gwama grow-1PL.EXCL.SBJ.PFV grain
'Until now we Gwama have been growing grain.'4

As in the closely related language Komo, independent subject and object pronouns are identical (see Burns (1947:14) for Komo). This is illustrated with the third person plural pronouns in example (2) (both of these sentences were elicited independently rather than forming part of a text).
a. hún
dè-bùn
Sá páàkà
3MPL.SBJ NEG-3PL.SBJ.NEG eat injera
'They are not eating injera.'
b. ga fú-ní hún
1SG.SBJ love-1SG.SBJ.PFV 3MPL.OBJ
'I love them.'

According to Zelealem (2005:8), subject and object pronouns have contrastive vowel length with objects having long vowels. However, Hellenthal and Kutsch Lojenga (2011:2) do not find vowel length to be distinctive in Gwama (see also Hellenthal n.d.:§3.4). The exact form of the object pronouns requires further investigation.

Another difference with Zelealem (2005) is found in the form for the third singular masculine pronoun. Zelealem (2005:8) omits the initial $u$. Note the presence of this vowel both in subject and object forms in example (3) (all clauses from nontextual elicited data).
a. úháy
dè-bè
Já
páàkà
3MSG.SBJ
NEG-3MSG.SBJ.NEG eat
injera
'He is not eating injera.'

\footnotetext{
${ }^{4}$ As much as possible, we have restricted the examples for this paper to ones in which tone is marked. However, for some of the data elicited, such as the text from which this example was taken, tone was not recorded. Such examples may still be illustrative of certain grammatical features being discussed. Note also that where personal names are changed, the substituted names are given without their tones.
} 
b. ùháy gà $\quad$ í-nè- $\int 1$

3MSG.OBJ 1SG.SBJ know-1SG.SBJ-PFV-know

'I know him.'

c. ga ni-tí kééfé k’áf uhày

1SG.SBJ 1SG.SBJ.IPFV-give gourd to 3MSG.OBJ

'I am giving the gourd to him.'

If the vowel $u$ here is the singulative prefix that is also found on nouns (discussed in section 10.3 below), the question remains why it does not appear on other pronouns, notably the third person feminine singular form, a question that remains to be answered.

(b) Possessive pronouns. Possessive pronouns follow the genitive marker $a$. They are illustrated in example (4) for kinship (a), ownership (b), and part-whole (c). Note that only the first person plural forms of the possessive pronouns are identical to the subject pronouns. (Note also the variant form $\dot{\varepsilon}$ of the genitive marker in example (c).)

a. wàl-kwám á ná á-ná-kì úne úúgú child-father GEN 1SG.POSS IPFV-3MSG.SBJ.IPFV-put into gourd 'My brother puts it into the gourd.'

b. gìtà hój̀ wàp' Já-ná-fàá when come pig eat-3MSG.SBJ.PFV-RED kàp-mì Jín à mà take-1PL.EXCL.SBJ.PFV spear GEN 1PL.EXCL.POSS

'When a pig comes to eat, we take our spear.'

c. úp $\dot{\varepsilon}$ dé tòtó kò-mé t'wà zìzííní head GEN 3MSG.POSS bring put-1PL.EXCL.SBJ.PFV mouth fence 'We bring its (the pig's) head and put it on the compound fence.' 
Zelealem (2005:8) treats the genitive marker as part of the possessive pronoun. However, since the same marker is used in possessive phrases (see section 13 below), it is more appropriately treated as a separate word.

4.2 Pronominal affixes. (a) Imperfective. The imperfective subject pronominal affixes follow the imperfective prefix $a$-, as illustrated in example (5).

(5) gìdè p’á-mè-p’á

when dance-1PL.EXCL.SBJ.PFV-RED

á-mè-yì-yìs t’wà zìzííní

IPFV-1PL.EXCL.SBJ.IPFV-circle-RED mouth fence

'When we dance, we circle around the compound fence.'

In examples where this imperfective marker appears to be missing it may have elided following the vowel $a$; slower, more carefully enunciated speech may reveal its presence.

(b) Perfective. Perfective pronominal subject suffixes are illustrated in example (6) with a simple root in (a) and a reduplicated root in (b). In the latter, the pronominal affix occurs between the two root morphemes (see also $p$ 'á-mè-p'á 'we dance' in example (5) above). Because of pronominal marking on the verb, an overt subject is not required.
a. s'ít-ní
gí màn
twáàsén
have-3MSG.SBJ.PFV
ACC children three
'He has three children.'

b. mà-bàábá

gìdà hìm-bí-hìm

jìn-kò

PL-father

when $q$

dà-bòn

$$
\text { hó k'á kàsàs }
$$

ED past-ADV

NEG-3PL.SBJ.NEG go to

accusation place chief

'Our fathers, when they quarreled in the past, did not go to the place of judges to bring an accusation.' 
(c) Negative. Negative subject pronominal affixes attach to the negative auxiliary, as shown in example (7). The affixes are uninflected for tense.
a. dè-bùn
wé óóỳ̀
NEG-3PL.SBJ.NEG wear clothes
'They didn't wear clothes.'
b. gírì dà-mà s'ìt
coins NEG-1PL.EXCL.SBJ.NEG have
'Coins we don't have.'

(d) Passive. Passive subject pronominal affixes are illustrated in example (8). Note that the verb root is reduplicated in the passive.
a. kí-k-yáàtà
á nà
nukta
kò-báb-kò
CLF-person-female GEN 1SG.POSS Nukta 'My wife is called Nukta.'

b. gaya kj̀-bún-kj̀

Oromo call-3PL.SBJ.PASS-RED

'They are called Oromo.'

For the third person plural, an alternative, longer form is also attested, as shown in example (9). Possibly, the difference in form is due to the difference in tense/aspects, the longer form being used for past tense. This calls for further investigation. Note also the absence of verb reduplication with the second occurrence of the long form in the same sentence that has the reduplicated form. Further data will be needed to clarify this apparent inconsistency.

\footnotetext{
${ }^{5}$ Personal names in the examples have been altered to ensure the privacy of the individuals concerned.
} 
(9)

gide pì-búgún-pì mà-sàkó

when give.birth-3PL.SBJ.PASS-RED PL-grandfather

pì-búgún gì yís zíyánkò

give.birth-3PL.SBJ.PASS with body naked

'When our grandfathers were born, they were born with naked bodies.'

Zelealem (2005:17) shows the passive marker as being $b a$ - followed by the subject marker. ${ }^{6}$ Although the form $b a$ - can be traced in some of the forms, it appears in the present data that the passive marker has amalgamated with the subject pronoun. This is another instance where the data for this research differs significantly from that presented in Zelealem (2005).

Note that the short form of the third person plural passive is identical in form to the third person plural negative affix and, aside from its being an affix, to the independent third person plural possessive pronoun.

\section{Demonstratives}

There are two sets of demonstrative pronouns: proximal and distal. Each set is inflected for gender and number, as shown in Table 4. Slashes indicate variant forms. (Note that tone was not marked when this data was recorded.)

Table 4. Demonstrative pronouns.

\begin{tabular}{|c|c|c|c|c|}
\hline & \multicolumn{2}{|l|}{ Proximal } & \multicolumn{2}{|l|}{ Distal } \\
\hline & $\mathrm{SG}$ & PL & $\mathrm{SG}$ & PL \\
\hline M & $\begin{array}{l}\text { ute kikeezi } \\
\text { 'this man' }\end{array}$ & $\begin{array}{l}\text { anun kikeezi } \\
\text { 'these men' }\end{array}$ & $\begin{array}{l}\text { uni/ani kikeezi } \\
\text { 'that man' }\end{array}$ & $\begin{array}{l}\text { aton kikeezi } \\
\text { 'those men' }\end{array}$ \\
\hline $\mathrm{F}$ & $\begin{array}{l}\text { oo kikjata } \\
\text { 'this woman' }\end{array}$ & $\begin{array}{l}\text { anun kikjata } \\
\text { 'these women' }\end{array}$ & $\begin{array}{l}\text { ato/ate kikjata } \\
\text { 'that woman' }\end{array}$ & $\begin{array}{l}\text { aton/ate kikjata } \\
\text { 'those women' }\end{array}$ \\
\hline
\end{tabular}

\footnotetext{
${ }^{6}$ Except for the third person masculine singular, Zelealem (2005) does not describe what the subject markers for the passive are in his section 3.5 which discusses the passive structure. A comparison with his example (12) on p.12 suggests that the subject markers for the passive are identical to the object pronominals for verbs that mark both subject and object.
} 
While in these paradigms, the demonstrative occurs before the noun it modifies, in the texts the order is the opposite. This may indicate flexibility. Certainly it requires further investigation.

Demonstrative pronouns may be used independently, as in example (10).

gìdà gèlè-báằ nà àtè màánpéć kò-pá-kj̀
when drive-3PL.SBJ.PFV goat those.F niece call-3PL.SBJ.PFV-RED
'When they drive goats, those (females) they call nieces.'

A demonstrative clitic that attaches to the end of a noun or noun phrase is also used. It has two forms: -tè (M) and -tò (F). The latter is illustrated in example (11).

(11) gide pé̃́̃ns'gí dwá dwá-tò fé yá-kwà bíyá
when pay with girl girl-the.F also 3FSG.SBJ.IPFV-do what
'When they have paid with the girl, that girl also, what does she do?'7

\section{Prepositions and postpositions}

The most common preposition is gi. It signals that the following noun has an unspecified kind of adverbial relation to the verb. Example (12) illustrates its use to mark temporal location (a) and instrument (b).
a. só-ní-gé
gì sùgùn
spear-1SG.SBJ.PFV-3MSG.OBJ at night
'I spear it (i.e., the pig) at night.'

b. mà

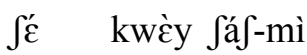

1PL.EXCL.SBJ also hoe eat-1PL.EXCL.SBJ.PFV

gì gàáfá mà-bàbá

with hoe PL-father

'We also hoe in order to eat, with a hoe like our fathers.'

\footnotetext{
${ }^{7}$ In Gwama culture, when a man kills another man, he must give a girl from his family as wife to the dead man's family as payment.
} 
Some prepositions are grammaticalized nouns. Examples are shown in Table 5. Further research may reveal others.

Table 5. Nouns functioning as prepositions.

\begin{tabular}{|l|l|l|}
\hline & Noun & Preposition \\
\hline kwás & 'back' & 'behind' \\
\hline tát & 'stomach' & 'in' \\
\hline t’wà & 'mouth' & 'around' \\
\hline wúús & 'sky' & 'on' \\
\hline
\end{tabular}

Example (13) illustrates the preposition tát 'in,' as well as two other prepositions, búgúnè 'around' and idágà 'among.'

a. má gwàmá bílé zè̀े-má 1PL.EXCL.SBJ Gwama when live-1PL.EXCL.SBJ.PFV tát wàwàn $\tilde{\varepsilon} y \tilde{\varepsilon}$ kwéć-me síyàná in grass hut cultivate-1PL.EXCL.SBJ.PFV grain 'When we Gwama lived in grass huts, we cultivated grain.'

b. kàp-bí wáànà-wáày sùyà ù-séćné bring-3PL.SBJ.PFV chicken-RED two SGV-one bà-pí búgúnè úp circle-3PL.SBJ.PFV around head

'They bring two chickens and circle one around the head.'

c. máỳ̀ hò kès-bá idágà gwàmá Bertha come enter-3PL.SBJ.PFV among Gwama 'The Bertha came and entered among the Gwama.'

Example (14) illustrates the postposition páy 'without.' This may have a different origin from the prepositions. 
(14) hò tò-tò kò-bé iyìsá kòjî yyá jóyc̀ pán come take-RED put-3PL.SBJ.PFV body skin goat clothes without 'They come and take the body and put it on the goat skin without clothes.'

\section{Adverbs}

Adverbs ending with the suffix $-k s$ or $-k o$ indicate manner or time. Table 6 illustrates adverbs of manner. The form of the adverb is not inflected for number as seen by comparing the singular and plural forms for 'walk slowly' in this table.

Table 6. Adverbs.

\begin{tabular}{|l|l|l|}
\hline Verb & Adverb & Gloss \\
\hline t'wá & nàzní-kò & 'Speak loudly! (SG)' \\
\hline t'wá & t'éyák'à-kó & 'Speak quietly! (SG)' \\
\hline hó & t'éyák'à-kó & 'Walk slowly! (SG)' \\
\hline mí-hò & t'éyák'à-kó & 'Walk slowly! (PL)' \\
\hline
\end{tabular}

Example (15) illustrates the use of the affix with adverbs of time.

a. sìt múmún fîn-kó

bàj-bí

Swí

person spirit past-ADV make-3PL.SBJ.PFV beer

ún-bá

kòónó

add-3PL.SBJ.PFV pot

'In the past, local prophets made beer and added it to the pot.'

b. gí ót-kó

à-nà-twí

mánì gwà

in morning-ADV

IPFV-1SG.SBJ.IPFV-cal

children brother

à nà táb-á

GEN 1SG.POSS follow-IPL.EXCL.SBJ.PFV see

Jí ú-wàp

'In the morning I call my brothers and we follow the pig and see it.' 
Not all adverbs of manner and time take this suffix, however, as illustrated in example (16). The absence of the suffix in (c) may be due to the fact that bàdén is a loanword from Arabic.
a. bili
ze-mí
gí kéf̌́n
like.this be-1PL.EXCL.SBJ.PFV in today
'Like this we are today.'

b. u-kwe ko-ni-ko

ga

SGV-elephantsay-3MSG.SBJ.PFV-RED 1SG.SBJ

ni-gusa paj ik

1SG.SBJ.IPFV-run fast 2SG.SBJ

'The elephant said, "I run faster than you.",

c. bàdén sìt-è kú-kwám ábúm kù kwòó

afterwards person-PLPL-father 3PL.OBJ call say

á-mí-bà $\quad$ Jwì

IPFV-2PL.SBJ.IPFV-make beer

'Afterwards, the elders call and say, "You (PL) will make beer.",

The same suffix is also found on some adjectives, as shown below.

\section{Adjectives}

There are two ways of expressing attributes in Gwama: as adjectives and as verbs. The former is illustrated in example (17). The latter is discussed below in section 11.6. Note that the adjective follows the noun it modifies.
a. á-s'íw ù-sit
gàátá
$\mathrm{g} \dot{\mathrm{\varepsilon}} \mathrm{l} \dot{\mathrm{\varepsilon}} \mathrm{ba}$ nà IPFV-die SGV-person old drive-3PL.SBJ.PFV goat
'When an old person dies, they drive goats.' 
b. gide kwè-bí-kwè kwé ìf-bí

when hoe-3PL.SBJ.PFV-hoe hoe sleep-3PL.SBJ.PFV

gì yís zíyán-kj

with body naked-ADJ

'When they hoed, they hoed and slept with naked bodies.'

c. u-kalawandi ho k'afa-ni u-kwe

SGV-squirrel go deceive-3MSG.SBJ.PFVSGV-elephant

oya haant-ko ho-ni ze-ni

2SG.SBJ ${ }^{8}$ big-ADJ come-IMP live-IMP

'The squirrel deceived the elephant, "You are big. Come, live with me."

Adjectives may be reduplicated with diminutive meaning.

(18) ho-ni kwe wal-wal dàdó sèèn ini

come-IMP hoe small-RED job one here

'Come and hoe. There is one small job here.'

\section{Numerals}

Gwama numerals follow a base-five system, as suggested by the numbers $1-10$ in Table 7.

Table 7. Numbers $1-10$.

\begin{tabular}{|ll|ll|}
\hline sććsk'ín & 'one' & kúpà-sćn & 'six' \\
\hline swíyá & 'two' & kúpá-swíjá & 'seven' \\
\hline twàsćn & 'three' & kúp-twàsēn & 'eight' \\
\hline béés'ín & 'four' & kù-béés'ín & 'nine' \\
\hline kómòt' & 'five' & k'oos'i & 'ten' \\
\hline
\end{tabular}

8 Possibly this is an emphatic pronoun which may be used either with or without the regular subject pronoun. In the same narrative, the following phrase occurs: ik ukoya haantko 'you (emphatic?) are big.' This needs further investigation. 
Zelealem (2005:37) gives the form àsiyéné for 'one.' In the texts for this study both sćéné (sometimes prefixed with à or $\grave{u}$ ) and sćéskí(n) occur, as shown in example (19).
a. á-ní-s'ít
à-té
wál kí-kí-zà
IPFV-3MSG.SBJ.IPFV-catch PURP-give child CLF-person-male s'́ćné gí wàl kí-kí-yátà sééné one and child CLF-person-female one

'They catch in order to give one boy and one girl (lit. He catches to give one male child and one female child).'
b. $\int \varepsilon-z o-b i ́$
wal wàn
sééskí
slaughter-?-3PL.SBJ.PFV child chicken one
'They slaughter one chicken.'

Further study will be needed to understand the difference between these forms as

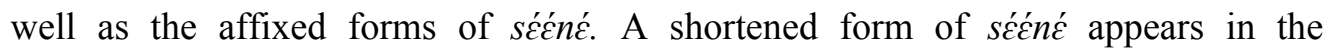
expression kúpà-sćn for the number 'six.'

The numbers 'six' to 'nine' consist of the root kup or kù- 'head' followed by the number 'one' to 'four.' For example, the word for 'seven' is the root kup followed by 'two.' Zelealem (2005:22) suggests that the origin for this root in the numbers 6-9 is the verb kubä meaning 'take/lend/bring' but this seems unlikely, especially considering that the word for 'twenty' takes as its root yisé 'body.'

Table 8 lists the numbers 11-20. Note that the word for 'twenty' also uses a shortened form of sćénć, as does the number 'six.'

Table 8. Numbers 11-20.

\begin{tabular}{|c|c|c|c|}
\hline kóózìòtè-s̄̄n & 'eleven' & kóózì̀t-kúpá-sćn & 'sixteen' \\
\hline kóózì̀tè-swíjà & 'twelve' & kóózì̀̀t-kúpá-swíyá & 'seventeen' \\
\hline kóózì̀̀t-twàsén & 'thirteen' & kóózì̀t-kúbá-twààsēn & 'eighteen' \\
\hline kóózìt-béés'én & 'fourteen' & kóózì̀t-kù-béés'ćn & 'nineteen' \\
\hline kóózì̀th-kómòt' & 'fifteen' & yíś́-sćné & 'twenty' \\
\hline
\end{tabular}


With numbers above 'one,' the noun does not need to be marked for plurality. This is illustrated in example (20). Note that no plural marker is used on the word kikyáta 'wife' with the number 'two,' although in the same clause the number 'seven' does take a plural noun, màn 'children.'

$\begin{array}{lllll}\text { s'ít-ni } \quad[k i ́-k-y a ́ t a & \text { swíyá] } & \text { ćè } & \text { gí } \\ \text { have-3MSG.SBJ.PFV CLF-person-female } & \text { two } & \text { INTER } & \text { and } \\ \text { [màn kùbá-swíyá] } & & & \\ \text { children seven } & & & \\ \text { 'He has two wives and seven children.' } & & \end{array}$

From this it seems that with numbers above 'one,' a singular noun is used unless there is a separate plural form available. Further study will be needed to substantiate this conclusion.

\section{Nouns}

Table 9 illustrates the possible structures of nouns. Affixation is minimal with nouns. As shown in the table, nouns may be unaffixed or have one prefix and/or one suffix. The different structures presented in the table are discussed below.

Table 9. Noun structures.

\begin{tabular}{|c|c|c|}
\hline Prefix & Root/stem & Suffix \\
\hline & $\begin{array}{l}\text { mit' } \\
\text { hand }\end{array}$ & \\
\hline & $\begin{array}{l}\text { wàl-kwám } \\
\text { brother (lit. child-father) }\end{array}$ & \\
\hline & $\begin{array}{l}\text { is } \\
\text { sesame seed }\end{array}$ & $\begin{array}{l}-\mathrm{ku} \\
\mathrm{PL}\end{array}$ \\
\hline $\begin{array}{l}\text { má- } \\
\text { PL }\end{array}$ & $\begin{array}{l}\text { bàábà } \\
\text { father }\end{array}$ & \\
\hline $\begin{array}{l}\text { kí- } \\
\text { CLF }\end{array}$ & $\begin{array}{l}\text { kí } \\
\text { person }\end{array}$ & $\begin{array}{l}\text {-zà } \\
\text { male }\end{array}$ \\
\hline
\end{tabular}


10.1 Types of roots and stems. A noun root may be a simple noun, such as tàm 'honey' in example (21).
(21) hò-nì
tóp tàm
come-IMP drink honey
'Come and drink honey.'

Examples of reduplicated roots are given in Table 10. Note in $t^{\prime} a p^{\prime}-t^{\prime}$ 'áp' 'fetus' that the two roots do not necesssarily have identical tones.

Table 10. Reduplicated noun roots.

\begin{tabular}{|l|l|}
\hline hòf-hó $\int$ & 'lung' \\
\hline búúm-búúm & 'drum' \\
\hline t'àp'-t'áp' & 'fetus' \\
\hline sí $\phi$-sí $\phi$ & 'light rain' \\
\hline bùlú-bùlù & 'butterfly' \\
\hline
\end{tabular}

The reduplication may be partial with the reduplicated syllable consisting only of $\mathrm{CV}$, as in the words mú-mún 'spirit' and wá-wàn 'grass.' These examples suggest that the reduplication is from right to left with the reduplicated syllable only copying the first consonant and vowel of the original part. Alternatively, a second process after reduplication truncates the first element. The same process is evident with some reduplicated verbs. Note again in wá-wàn 'grass' that the tone on the two elements of the reduplicated noun stem may not be identical.

A noun stem may consist of a compound noun, such as wàl-kwám 'brother' (lit. child-father) in example (22). The absence of the genitive marker and the idiomatic meaning suggest this is indeed a compound noun rather than a noun phrase.

wàl-kwám á ná á-ná-kì úne úúgú child-father GEN 1SG.POSS IPFV-3MSG.SBJ.IPFV-put into gourd 'My brother puts it into the gourd.' 
The root of a noun may be a proper noun, as in example (23). Note that in this particular example, the two proper names (referring to two individuals) are both prefixed by the singulative prefix $u^{\prime}$, which is discussed below. (Note, however, that because the personal names have been altered for this paper, tone is not marked on them.)

(23) tàb kwásà [u-dibab] [u-kinan] bungul demis

follow after SGV-Dibab SGV-Kinan Bungul Demis

kò-bé-kò

call-3MSG.SBJ.PASS-RED

'After Dibab comes one called Kinan Bungul Demis.'

A noun root may be derived from a verb, as is the case with the noun glossed as 'the one who died' in example (24). (Note here too the singulative prefix $\grave{u}-$.)

í-yásà kwaba tó-tó kò ù-s'í-tè

DAT-place several.people take-RED put SGV-die-the

'Several people take the one who died and put him in that place.'

10.2 Noun classes. At least five classes of nouns may be identified in Gwama based on the marking (or lack thereof) of singular and plural. These are presented in Table 11. Some nouns mark the plural while others mark the singular; others mark neither the singular nor the plural. In addition, some nouns use suppletion to mark the difference between singular and plural. The five classes are discussed below.

Table 11. Noun classes.

\begin{tabular}{|l|l|l|}
\hline Class & Singular & Plural \\
\hline 1 & no affix & no affix \\
\hline 2 & no affix & ma- \\
\hline 3 & -ku, u- & no affix/-a \\
\hline 4 & noun 1 & noun 2 \\
\hline 5 & $?$ & no affix \\
\hline
\end{tabular}


The variety of prefixes and suffixes suggests these classes of nouns may have different origins - which is a topic for further investigation. Most nouns belong to class 1 in which both singular and plural are unmarked. For these nouns, number must be inferred from the context. This is illustrated in example (25).
a. Jîg á màn á nà name GEN children GEN 1SG.POSS

'The names of my children are...'

b. ate wèt-mé wàl-kwàm then become-1PL.EXCL.SBJ.PFV child-father 'Then we have become brothers.'

Class 2 nouns are unmarked for singular but have a plural affix. As shown in Table 12 , most nouns with the prefix $m a$ - refer to humans.

Table 12. Nouns with $m a$ - plural prefix.

\begin{tabular}{|l|l|}
\hline má-bàába & 'fathers' \\
\hline má-sàkó & 'grandfathers' \\
\hline má-íkàká & 'grandmothers' \\
\hline ma-kekeezi & 'men' \\
\hline ma-ná & 'goats' \\
\hline
\end{tabular}

Note, however, in Table 12 that the word for 'goat' also takes the plural marker ma-. This is consistent with what is found to be the case in Northern Gumuz, where the prefix $m a$ - is used to mark the plural for nouns referring to people as well as livestock (Ahland 2010:2.1.6). Zelealem (2005:15) also records the $m a$ - prefix with the word for 'horses' (another livestock animal) but also 'cats' and even some body parts and the word for 'rivers.'

The plural marker is illustrated in example (26). Note in this example that the human-referring nouns are marked, while the word $s$ ' $i$ 'rats' is unmarked. (The 
context makes it clear that the reference is to more than one rat.) Perhaps the significant semantic criterion is domesticated versus non-domesticated animals.

\begin{tabular}{lllll} 
gí Jín-kó s'í gìdè $\quad$ fá & k'ú-ní & \\
in past-ADV rat & when eat & finish-3MSG.SBJ.PFV \\
sàmún sìt-á & má-sàkó & má-íkàká & hó \\
corn & person-PL PL-grandfather & PL-grandmother go \\
sò-bí & \multicolumn{2}{c}{ k'ònzí $\quad$ Já } & &
\end{tabular}

dig-3PL.SBJ.PFV root eat

'In the past, when rats ate all the corn, people-(our) grandfathers and grandmothers - went and dug and ate (bamboo) root.'

There are other plural affixes as well. For example, the word sit 'person' takes a plural suffix - $a$ as shown in example (27).

sit'-a kú-kwàm gida tú-tú t'wà-nú-t'wà person-PL PL-father when ask-RED tell-3MSG.SBJ.PFV-RED 'The elders ask and tell them...'

Note the use of the singular subject suffix -nu on the final verb in this example even though the subject of the verb is plural. In Gumuz a singular affix is commonly used with a plural subject and a plural suffix is used only to emphasize the individuality of the people involved (C. Ahland, pers. comm.). This is a topic for further research. The noun kwám 'father' takes the plural prefix kú-, as shown in example (28).

(28) bàdén sìt-غ̀ kú-kwám ábúm kù kwòó

afterwards person-PL PL-father 3PL.OBJ call say á-mí-bà $\quad$ Jwì

IPFV-2PL.SBJ.IPFV-make beer

"Afterwards, the elders call them and say, "You (PL) will make beer."”

An alternative interpretation of the $k u$ - prefix analyzes it as an allomorph of the ancient classifier prefix $k i$ - discussed below in section 9.3. 
Class 3 nouns take a singulative marker $\grave{u}$-. There may or may not be a plural marker. Some examples are given in example (29). In (a) the marker is used for 'God'; in (b) and (c) for humans (including proper nouns); in (d) for animals; and in (c) and (e) for inanimate objects. (Note that the texts from which examples (a) and (d) were taken did not mark tone while in example (b) the names were changed; tone is not marked on the substitutes.)

a. gidi halak-ni-ma

\section{u-yeqre}

when create-3MSG.SBJ.PFV-1PL.EXCL.OBJ SGV-God

tii-nI-ma-ge t'wa mene uwe

give-3MSG.SBJ.PFV-1PL.EXCL.OBJ-? language 1PL.INCL.POSS this

'When God created us, He gave us this our language.'

b. tàb kwásà u-dibab u-kinan bungul demis

follow after SGV-Dibab SGV-Kinan Bungul Demis

kò-bé-kò

call-3MSG.SBJ.PASS-RED

'After Dibab comes one called Kinan Bungul Demis.'

c. ú-páyàk'-tè tí-né-gé dèc̀ húnú

SGV-shell-the give-3MSG.SBJ.PFV-? show sickness

ì-ỳ̀s à ú-sìt húun-tè

DAT-body GEN SGV-person sick-the

'The shell shows the sickness in the body of the sick person.'

d. u-kalawandi ho k'afa-ni

SGV-squirrel go deceive-3MSG.SBJ.PFV

'The squirrel deceived the elephant.'

\author{
u-kwe \\ SGV-elephant
}


e. daz-a s'íg-mà-s'íg-í

grind-1PL.EXCL.SBJ.PFV knead-1PL.EXCL.SBJ.PFV-RED-REL

ate páf-mì ú-yádé

then cover-1PL.EXCL.SBJ.PFV SGV-dough

'When we have ground and kneaded, then we cover the dough.'

It might be argued that since example (d) is taken from a folk tale in which the animals are given human qualities, such as being able to speak, this example may not be indicative of how animals are normally handled in the grammar. This calls for an analysis of a text about animals in which they are not given human qualities.

Class 4 nouns indicate plurality by means of suppletion. This is illustrated in example (30). The word màn 'children' in (a) is the plural counterpart to the word wàl 'child' in (b).
a. pé-bí
màn dídí
bear-3PL.SBJ.PFV children new
'They bore new children.'

b. á-ní-s'ít

à-té

wál kí-kí-zà

IPFV-3MSG.SBJ.IPFV-catch PURP-give child CLF-person-male

sććné gí wàl kí-kí-yátà séćné

one and child CLF-person-female one

'They catch in order to give one boy and one girl (lit. He catches to give one male child and one female child).'

Class 5 nouns have only one form referring to a group, as illustrated in example (31). In this case, context determines whether the singular is intended, unless number is indicated by object marking on the verb. Unlike class 1 nouns, these nouns are plural by default.
(31) kúúrù dà-mà
s'ìt
donkey NEG-1PL.EXCL.SBJ.NEG have
'Donkeys we don't have.' 
10.3 the $\boldsymbol{u}$-prefix. Besides marking singulative (as discussed above in section 10.2), the prefix $\grave{u}$ - seems to have a discourse function as well. A particular noun may have the singulative prefix in one sentence and lack it in another sentence in the same text, even when in both cases the reference is singular. This is illustrated in example (32). In (a) kaana 'dog' does not take the marker while in (b), taken from a few lines further in the same text, it does.
a. ho kaana buk'
a- a-ni
pwa-te
come dog snatch PURP-eat-3MSG.SBJ.PFV porridge-the
'The dog came and snatched it (the porridge) away to eat it.'
b. ho-na ze
haygo' k'aja-no
wànú u-kaana
come-IMPlive together deceive-3MSG.SBJ.PFV fox SGV-dog
"“Come and let's live together," the dog deceived the fox.'

The $u$ - prefix may also be used with the numeral 'one' to refer to one person or one object, as shown in example (33).

$\begin{array}{lll}\text { ù-sćéné } & \text { bà-pí } & \text { búgúnè úp } \\ \text { SGV-one } & \text { circle-3PL.SBJ.PFV } & \text { around head }\end{array}$

'They circle one (chicken) around the (person's) head.'

Possibly, the prefix is used to contrast one person or object with another. The context for the sentence quoted in example (33) is given in example (34). The 'one' chicken is circled around the person's head and the (other) 'one' chicken is slaughtered.

$$
\begin{aligned}
& \text { a. kàp-bí wáàn-à-wáày sùyà } \\
& \text { bring-3PL.SBJ.PFV chicken-*-RED two } \\
& \text { 'They bring two chickens.' }
\end{aligned}
$$
b. ù-séćné bà-pí búgúnè úp
SGV-one circle-3PL.SBJ.PFV around head
'They circle one (chicken) around the head.'


c. gìdè bà-pí búgúnè úp=í $\quad \begin{aligned} & \text { ù-sćén } \\ & \text { when circle-3PL.SBJ.PFV around head=REL }\end{aligned}$ SGV-one
$\int \grave{\varepsilon}-b \bar{\varepsilon}-\int \grave{\varepsilon}$
slaughter-3PL.SBJ.PFV-RED
'When they circle one around the head, they slaughter the other one.'

It appears then that while the $u$ - prefix is limited to singular nominals, the label "singulative" does not fully capture its function. Although it is predominantly used with subject nominals, it also occurs with nouns functioning as objects (as seen in example (33) just quoted as well as in example (29) (e) above). Clearly, further research on the discourse level is needed to fully characterize this marker.

Zelealem (2005:29) quotes unpublished material from Bender in which the $u$ prefix is glossed as 'the.' This is clearly not an adequate translation.

10.4 ki- nouns. The prefix $k i-/ k^{\prime} i$ - found on some nouns is a remnant of an old definite article or classifier. It is found in many other Nilo-Saharan languages as well (see Greenberg 1990:47). Examples are given in Table 13 (from elicited data). Note that in the word t'wày-ki-t'wàyk 'scorpion' it occurs between the root and its reduplicated counterpart.

Table 13. ki-nouns.

\begin{tabular}{|ll|ll|}
\hline kí-kámbí & 'camel' & k'í-ánzà & 'instrument' \\
\hline t'wàn-kí-t’wànk & 'scorpion' & k'ì-'líitì & 'flute' \\
\hline k'í-'k'áỳsá & 'army ant' & kí-kízà & 'male' \\
\hline k'í-'k'ìj & 'tortoise' & kí-kyáàtà & 'female' \\
\hline k'í-fìn & 'bow' & & \\
\hline
\end{tabular}

The word ki-kámbi 'camel' is probably a loanword from Arabic gämäl and thus provides strong evidence that $k i$ - is indeed a prefix. Further support for this analysis comes from a comparison of some of the words with Gumuz. For example, the word gánda 'army ant' (in the Mandura dialect of Gumuz) is similar to k'áỳsá in k'ik’áỳsá, and gwinzá 'male' (in all Gumuz dialects) is similar to kízà in kí-kízà (data 
from C. Ahland, pers. comm.). The prefix kú- in kú-kúnùfú 'bow' and kú-kwám 'fathers' is possibly an allomorph of the same prefix.

Example (35) illustrates a $k i$ - noun with a plural marker, showing the relative ordering of the plural marker followed by the ki-prefix.

ak'as ho ho ho ma-ke-kee-zi kj̀-nà-kó

others go go go PL-CLF-person-male call-3MSG.SBJ.PFV-RED

'Others, the men, call, "Go! Go! Go!"”

\section{Verbs}

11.1 Structures. Gwama verbs may be grouped into four main categories, as presented in Table 14. Type 1 verbs consist of an unaffixed root or stem (i.e., a reduplicated root). Type 2 and 3 verbs take suffixes while type 4 verbs take prefixes. In type 3 verbs, the verb root is also reduplicated after the suffix(es).

Table 14. Types of verb structures.

\begin{tabular}{|l|l|l|l|l|l|l|l|}
\hline Type & \multicolumn{2}{|l|}{ Prefixes } & Root/Stem & \multicolumn{2}{l|}{ Suffixes } & \\
\hline 1 & & & & Root/Stem & & & \\
\hline 2 & & & & Root/Stem & SBJ & OBJ & \\
\hline 3 & & & & Root1 & SBJ & OBJ & Root2 \\
\hline 4 & TAM & SBJ & OBJ & Root & & & \\
\hline
\end{tabular}

The first verb structure is an unaffixed simple root or a stem consisting of a reduplicated root. This structure is illustrated in example (36) with a simple root in (a) and a reduplicated root in (b).
a. í-yásà kwaba
tó-tó kò ù-s'í-tè
DAT-place several.people take-RED put SGV-die-the

'Several people take the one who died and put him in that place.' 
$\begin{array}{llll}\text { b. bààdéní } & \text { gìdà } & \text { zè-gí } & \text { má-sàkó } \\ \text { after } & \text { when live-3PL.SBJ.PFV } & \text { PL-grandfather } \\ \text { kèc̀r-kò } & \text { sìt-à } & \text { s'í-s'í } & \text { ùbù má-à } \\ \text { past-ADV } & \text { person-PL } & \text { die-RED } & \text { village 1PL.EXCL.POSS } \\ \text { 'When our grandfathers lived in the past, people of our village died.' }\end{array}$

Frequently, unaffixed verb roots are used in a series of verbs called converbs before a final, inflected verb, as in example (37) (the series of verbs is marked with brackets). Note that only the last verb in the series is inflected-the opposite, incidentally, of what is found in the related language Komo, where it is the first verb in the series that is inflected (Burns 1947:23). (Converbs are discussed in more detail in section 12.1 below.)

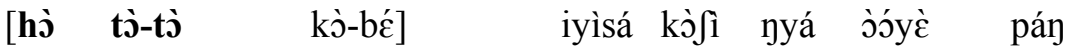
come take-RED put-3PL.SBJ.PFV body skin goat clothes without 'They come and take the body and put it on the goat skin without clothes.'

The second verb structure, which is also very common, involves the addition of a subject and/or object suffix to the simple or reduplicated root. A simple root is shown in example (37) above (the final verb in the series of verbs); a reduplicated root is shown in example (38).

gide ís sàmún òbù màá púnt'-má

when ripe corn village 1PL.EXCL.POSS cut-1PL.EXCL.SBJ.PFV

kj̀-kj̀-má swúy é-lògún

put-RED-1PL.EXCL.SBJ.PFV house on-wall

'When the corn is ripe in our village, we cut it and put it in (our) house on the wall.'

A verb with an object suffix is illustrated in example (39).

tí-mà púfdú

give-1PL.EXCL.OBJ tied.cotton

'Give us tied cotton.' 
When there is a subject pronominal, the object suffix always follows the subject suffix, as in example (40). Note here that the object suffix - ma follows the perfective subject suffix $-n i$ (here transcribed as $-n I$ ).

$\begin{array}{llll}\text { gidi } & \text { halak-nI-ma } & \text { u-yecre } & \\ \text { when } & \text { create-3MSG.SBJ.PFV-1PL.EXCL.OBJ } & \text { SGV-God } & \\ \text { tii-nI-ma-ge } & \text { t'wa } & \text { mene } & \text { uwe } \\ \text { give-3MSG.SBJ.PFV-1PL.EXCL.OBJ-? } & \text { language } & \text { 1PL.INCL.POSS this } \\ \text { 'When God created us, He gave us this our language.' } & \end{array}$

The third verb structure involves a reduplicated verb root with a subject (and sometimes an object) suffix occurring between the two root morphemes. Note the contrast with type 2 verbs, where the subject affix follows the reduplicated root. This verb type is illustrated in example (41) with a subject affix in (a) and both a subject and an object affix in (b).
a. gìtà kààm- $\varepsilon$-kààm
méć
when find-1PL.EXCL.SBJ.PFV-RED 1PL.EXCL.SBJ
s̀̀-mé-s̀̀

spear-1PL.EXCL.SBJ.PFV-RED

'When we find (it, i.e., the pig) we spear (it).'

b. gà-í Jìg á ná banti

1SG.SBJ-FOC name GEN 1SG.POSS Banti

marfo kj̀-bí-gà-kj̀

Marfo call-3PL.SBJ.PFV-1SG.OBJ-RED

'As for me, my name, they call me Banti Marfo.'

The fourth verb structure involves pronominal prefixes rather than suffixes. The verb root consists of a subject (and sometimes an object) prefix following the imperfective prefix, as shown in example (42). Note that while the affixes are now prefixed to the root rather than suffixed, the relative order of the affixes is still subject-object, as shown in (b). 

a. à-mè-kúj
gí ànt
IPFV-1PL.EXCL.SBJ.IPFV-blow.smoke with fire
'We blow smoke with fire.'
b. ùyáà
a-na-gà-tí
pòkám á
3MSG.SBJ
IPFV-3MSG.SBJ.IPFV-1SG.OBJ-give sister
GEN
dè gà p'íf nè-té pòkám á nà
3MSG.POSS 1SG.SBJ also 1SG.SBJ.IPFV-give sister GEN 1SG.POSS
'He gives me his sister [as a wife] and I also give (him) my sister [as a wife].'

Further analysis may uncover additional verb structures not presented here. One affix that is not included (because of very limited data) is the prefix $m a-$. It appears in a few clauses such as in example (43) and may be the past marker, analogous to the one presented in Zelealem (2005:11, ex. 9).
a. gide má-k'à mán swúya àté
when PST-eat children two those.F
'when those two children have eaten'

b. gìdà má-jà dàkí-bá-dàk

when PST-dig finish-3PL.SBJ.PFV-RED

'when they have finished digging'

In both of these clauses it is clear that this is not the subject pronoun má since the subject of the clause is third person plural (indicated in (a) by the noun phrase 'those two children' and in (b) by the pronominal on the verb). Note that in (b) the prefix is attached to the converb (discussed in section 12 below).

11.2 Verb tenses. (a) Perfective. The perfective may be used to narrate a text about the past, as in example (44). The two sentences are taken from two texts describing past lifestyles. 


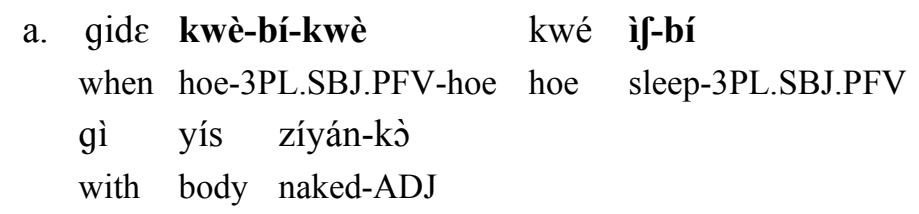

'When they hoed, they hoed and slept with naked bodies.'

$\begin{array}{lll}\text { b. sìt múmún } & \begin{array}{l}\text { Jîn-kó bàf-bí } \\ \text { person spirit }\end{array} \text { past-ADV make-3PL.SBJ.PFV beer } \\ \text { ún-bá } & \text { kòónó } \\ \text { add-3PL.SBJ.PFV pot } & \text { pó } \\ \text { 'In the past, local prophets made beer and added it to the pot.' }\end{array}$

The perfective may also be used to describe habitual activities, as in example (45). These two sentences are taken from texts that describe the present lifestyle of the people.

a. kap-mi gecnde hang-1PL.SBJ.PFV beehives ma top-mi tam 1PL.EXCL.SBJ take out-1PL.EXCL.SBJ.PFV honey 'We hang beehives (and) we take out honey.'

b. p'éénz-mì súmum p'áz-ma ken take.out-1PL.EXCL.SBJ.PFV corn soak-1PL.EXCL.SBJ.PFV like.this 'We strip corn and we soak it like this.'

(b) Imperfective. In its latter use discussed above, the perfective overlaps with the imperfective, which may also be used for narrative sequences. This is illustrated in example (46), which is taken from a text describing how honey is collected from a tree.

(46) wàl-kwám á ná á-ná-kì úne úúgú child-father GEN 1SG.POSS IPFV-3MSG.SBJ.IPFV-put into gourd 'My brother puts it into the gourd.' 
Sometimes, the imperfective is used to interject a comment in a text that uses the pefective throughout, as in the sentences in example (47), which seem to function as parenthetical comments in their respective texts.

a. gìdè p’á-mè-p’á

when dance-1PL.EXCL.SBJ.PFB-RED

á-mè-yì-yìs t'wà zìzííní

IPFV-1PL.EXCL.SBJ.IPFV-circle-RED mouth fence

'When we dance, we circle around the compound fence.'

b. à-bì-tí màn súyà súyà súyà

IPFV-3PL.SBJ.IPFV-give children two two two

'They give two children (to each chief, or two per family?).'

Many questions remain about the distinctions between the tenses. None of the verb conjugations described in Zelealem (2005:10-13) could be identified in the narratives used in this study.

11.3 Negation. Negation is accomplished by means of a negative verb, which is always inflected for subject. The forms of the negative auxiliary are listed in Table 15 along with the free subject pronouns for comparison.

Table 15. Negative verb.

\begin{tabular}{|c|c|c|}
\hline Person & $\begin{array}{l}\text { Negative } \\
\text { verb }\end{array}$ & $\begin{array}{l}\mathrm{SBJ} / \mathrm{OBJ} \\
\text { pronouns }\end{array}$ \\
\hline $1 \mathrm{SG}$ & dá-gá & ga \\
\hline $2 \mathrm{SG}$ & dé-bí & $\mathrm{ik}$ \\
\hline $3 \mathrm{MSG}$ & dé-bí & uhay \\
\hline $3 \mathrm{FSG}$ & dá-báb & hap \\
\hline 1PL.EXCL & dá-má & $\mathrm{ma}$ \\
\hline 1PL.INCL & $\mathrm{d} \varepsilon^{\prime}-\mathrm{m} \varepsilon$ & mecne \\
\hline $2 \mathrm{PL}$ & dá-búm & $\mathrm{um}$ \\
\hline $3 \mathrm{PL}$ & dá-bún & hun \\
\hline
\end{tabular}


Note the vowel harmony as [á] becomes [ć] before a front vowel. This is not a hard and fast rule, however, as the form dè-bùn is also attested (see example (7) above). Note also that the High tone on the forms as given here is from the paradigm as given in isolated form. In actual textual data, the tones may vary, as in example (54).

As illustrated in example (48), the negative verb is always the first in a series of verbs and carries the subject inflection. It never takes an object suffix. Time setting for negative clauses needs to be determined from the context or some time-reference such as the adverb finks 'in the past' in example (b).
a. t'wa gozom da-ma aya language Amhara NEG-1PL.EXCL.SBJ.NEG know 'The Amhara language we did not know.'

b. i-bírò dá-bùn Jè má-bàába Jin-ko FOC-office NEG-3PL.SBJ.NEG know PL-father past-ADV 'Our fathers did not know offices in the past (lit. Offices they did not know our fathers in the past).'

Imperatives use a different negative verb, bilgi, which is discussed below.

11.4 Imperatives. The singular imperative is an unaffixed verb form. Some verbs form their (singular) imperative by means of reduplication, as with $f f^{\prime}-f i$ 'bring' in example (49).

Jú-fí nà tí-yà k káf ù-wál-kwán
bring-IMP goat give-3MSG.OBJ to SGV-child-father
'Bring a goat and give it to (your) brother.'

Plural imperatives are formed with the addition of the prefix mí- as in mí-gùgùs 'run (PL)!' in example (50). (The prefix is possibly the 2PL imperfective form.) Note that in this example, following Zelealem (2005:19), we would have expected to find the form mí-gùs-a-gùs with what he calls a "linking element $a$." Possibly, mí-gù-gùs is a contracted form. 
(50)
gìdè $\int \hat{i}-m i ́$
gàyá mí-gù-gùs
when see-2PL.SBJ.PFV Oromo IMP.PL-run-RED
'When you (PL) see Oromos [ethnic group], run (away)!'

In the imperative, negation is indicated with the verb bilgi, as illustrated in Table 16. In the plural, the prefix $m i$ - is affixed to the negative verb root and not the main verb. It appears that in the negative imperative, the verb is never reduplicated.

Table 16. Negative imperative.

\begin{tabular}{|l|l|c|l|}
\hline \multicolumn{2}{|c|}{ Negative verb } & \multirow{2}{*}{ Main verb } & \multirow{2}{*}{ Gloss } \\
\hline Subject & Root & & \\
\hline & bìlgí & ż̀ & 'Don't sit! (SG)' \\
\hline mí- & bìlgí & ż̀ & 'Don't sit! (PL)' \\
\hline
\end{tabular}

The hortative ("let's...") consists of the first person inclusive plural prefix $n i$ followed by the verb root, as shown in example (51).
(51) ho
ni-tuta
ho
come 1PL.INCL.SBJ.IPFV-return go
'Come. Let's return and go (home).'

11.5 Verb 'to have.' The verb 'to have' is $s$ ' $i$, which is usually followed by a subject marker, as shown in example (52). Zelealem (2005:14) claims that this is a personal affix only, not inflected for tense, but it appears that this is actually the perfective suffix.

\begin{tabular}{llll} 
s'ít-ni & \multicolumn{1}{c}{ kí-k-yáta } & swíyá & ćè \\
have-3MSG.SBJ.PFV & CLF-person-female & two & INTER \\
gí màn kùbá-swíyá & & \\
and children & five-two & &
\end{tabular}

'He has two wives and seven children.' 
Note the alternative and synonymous expression in (53), which uses an existential verb rather than the verb 'to have.'
(53)
màn á na
zغ̀-bí
kùpá sènè
children GEN 1SG.POSS be-3PL.SBJ.PFV five one
'I have six children (lit. My children, they are six).'

Note, however, that this example comes from a text by a speaker whose first languages is Komo and may, therefore, be a translation from Komo. This is something that will need to be checked with native speakers of Gwama. Unfortunately, Burns (1947) does not describe the structure of the verb 'to have' in his notes on the grammar of Komo.

As with other verbs following the negative auxiliary, the verb 'to have' is uninflected when negated, as shown in example (54). Negation is marked on the auxiliary instead.
ććm dà-mà
s'ìt
ox NEG-1PL.EXCL.SBJ.NEG have

'Oxen we don't have.'

See example (94) below for an uninflected form of the verb 'to have' in an adjectival clause.

11.6 Reduplication. A common feature of Gwama verbs, reduplication is triggered by a number of factors. As discussed in section 4.2 (d) above, passive voice is formed by reduplicating the verb root separated by the passive affix. Furthermore, as shown in section 11.4, some verbs form their imperative by reduplicating the root. Another function of reduplication is to indicate attributes that in English would be expressed as adjectives, as shown in example (55).
gumunə seene twi-be néyè kànz-ní-kanza other one call-3PL.SBJ-PFV stone be.red-3MSG.SBJ.PFV-RED 'The other one they call "red stone (lit. the stone is red).", 
Note that like "regular" adjectives (see section 8 above), this "verbal adjective" also follows the noun it modifies.

Zelealem (2005:11-12) indicates that reduplication is also used to mark certain verb conjugations, including the present and past continuous. While the verb form bears little resemblance to that given for the past continuous in Zelealem (2005:12), this may explain the use of reduplication for the verbs that are highlighted in example (56).

a. gide kwè-bí-kwè kwé ìj-bí

when hoe-3PL.SBJ.PFV-hoe hoe sleep-3PL.SBJ.PFV

gì yís zíyán-kò

with body naked-ADJ

'When they hoed [or: while they were hoeing], they hoed and slept with naked bodies.'

b. gìdè p’á-mé-p'à

when dance-1PL.EXCL.SBJ.PFV-RED

tò̀̀t-bé kó kwìf-bé-kwìjî

take-3PL.SBJ.PFV put skin-3PL.SBJ.PFV-RED

'While we are dancing, they take [the tiger] and put it down and skin it.'

Reduplication may have other functions as well, such as indicating repeated action as in example (57) for frying corn (a) and for taking out scoops of honey from a beehive (b).

a. àtémá t'ò-t'’̀

then 1PL.EXCL.SBJ RED-fry

'Then we fry it (i.e., the corn).' 

b. gìdà má mè-k'òpè t'wí when 1PL.EXCL.SBJ 1PL.EXCL.SBJ.IPFV-cut widen bò tàm í-yàs zé tàm-í hole honey LOC-place be honey-REL

\section{á-mغ̀-tóp غ̀-tóp ع̀}
IPFV-1PL.EXCL.SBJ.IPFV-take.out-RED
'When we have cut to widen the honey hole in the place where the honey is, we take it out.'

Similarly, in example (58), reduplication may be used to indicate actions performed by multiple agents.

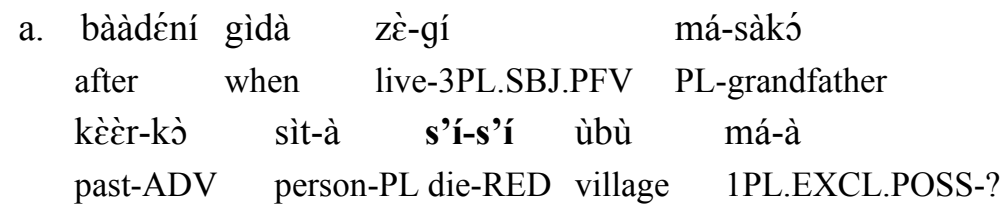

'When our grandfathers lived in the past, people of our village died.'

b. mà-bàábá gìdà hìm-bí-hìm Jìn-kj̀

PL-father when quarrel-3PL.SBJ.PFV-RED past-ADV

'when our fathers quarreled in the past'

That reduplication is at least partly a stylistic matter is evident from example (59), which presents two nearly identical clauses from the same text. In both clauses the initial verb in the expression 'began to wear' is reduplicated. However, only in (a) is the main verb 'wear' reduplicated while in (b), which immediately follows (a) in the text, the same verb is not reduplicated.
a. kú sú-sú
wé-bí-wé
ว́วyว
3PL.SBJ? begin-RED
wear-3PL.SBJ.PFV-RED
clothes
'They began to wear clothes.' 
b. ina sú-sú wé-bí jóyó

mothers begin-RED wear-3PL.SBJ.PFV clothes

'Mothers began to wear clothes.'

Example (60) presents a similar contrast between two instances of the same verb which is reduplicated on one occasion and not reduplicated later on in the text.

(60) a. kú-mà-kú

carry-1PL.EXCL.SBJ.PFV-RED

'We carry it (i.e., firewood).'

b. kú-mà úúp

carry-1PL.EXCL.SBJ.PFV head

'We carry on our head.'

A possible explanation is that reduplication is used to highlight the action of the verb itself.

As is evident from this discussion of verb reduplication, further investigation is required. For the related language Komo, Burns mentions reduplication in that language as used "in some contexts" for continuous action as well as to indicate "something done for no reason - 'just doing it"” (Burns 1947:22).

11.7 Copula. A copula is not normally used, as shown in example (61).

(61)
[túl a nàs] [késèr $\left.{ }_{\mathrm{SC}}\right]$
place GEN 1SG.POSS Keser
'My place is Keser.'

However, in the case of locatives, the personal subject pronoun functions something like a copula, as shown in example (62).

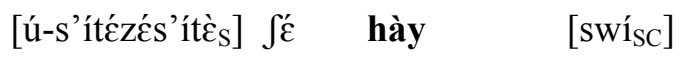

SGV-corpse also 3MSG.SBJ house

'The corpse also is in the house (lit. The corpse also he house).' 


\section{Verb phrases}

12.1 Converb and finite verb. A common feature in Gwama grammar - and one which it shares with other Afroasiatic and Nilo-Saharan languages in northeastern Africa (see Amha and Dimmendaal 2006:394) - is the presence of converbs. These non-finite verb forms appear as part of a series of closely related verbs in which only the last (or in some instances, as will be discussed below, the first) verb carries a pronominal marker indicating person, number, and tense/aspect. While converbs may be reduplicated, they lack the pronominal affix(es). Converbs are used in two different situations in Gwama.

(a) Consecutive converbs. In the first situation, the converb and main verb constitute a series of sequential actions arranged in temporal order-what Hetzron calls the "consecutive" function of converbs (Hetzron 1972:99-100, as quoted in Amha and Dimmendaal 2006:412). This is the situation described in Zelealem (2005:31) as sentences that lack "connectives" and where a converb precedes the main verb. "In such constructions," he says, "the action performed first appears preceding the action that follows" (Zelealem 2005:31).

Example (63) illustrates this situation. In (a) the two actions are 'hoe' and 'sleep'; the first is a converb while the second (probably intended as happening subsequently) is a finite verb that carries the pronominal suffix. In (b) the two actions are 'bring' and 'put.' Again, the verbs appear in the order that mirrors the sequence of actions in real life.

a. gide kwè-bí-kwè kwé ìf-bí

when hoe-3PL.SBJ.PFV-hoe hoe sleep-3PL.SBJ.PFV

gì yís zíyán-kò

with body naked-ADJ

'When they hoed, they hoed and slept with naked bodies.'

$\begin{array}{lllrll}\text { b. úp } & \varepsilon & \text { dé } & \text { tòtó } & \text { kò-mé } & \text { t'wà zìzíiní } \\ \text { head } & \text { GEN } & \text { 3MSG.POSS bring } & \text { put-1PL.EXCL.SBJ.PFV } & \text { mouth fence }\end{array}$

'We bring its (i.e., the pig's) head and put it on the compound fence.' 
Note that rather than "main verb" (the term used in Zelealem 2005:31), it may be more accurate to use the term "finite verb" since the two actions seem to be equally significant. The translations in Zelealem (2005:31, his example (19)), which express the converb by means of a participle (as in 'having drunk,' indeed give the impression that the finite verb is more in focus but this may not be entirely accurate.

Two converbs may precede a finite verb, as illustrated in example (64). Note in this example that while the second converb is reduplicated (which may be lexically determined), only the final verb is inflected with the pronominal affix.

(64) hò tò-tò kò-bé iyìsá kòjî̀ yyá job́yè páy come take-RED put-3PL.SBJ.PFV body skin goat clothes without 'They come and take the body and put it on the goat skin without clothes.'

In addition to the actions being sequential, the finite verb may also express the purpose of the action described by the converb. This is illustrated in example (65). Sometimes the finite verb contains a prefix $a$-indicating purpose. It is not clear why this prefix is absent in (a).

$\begin{array}{lll}\text { a. } & \text { mà } & \int^{\prime} \quad \text { kwèy fáf-mì } \\ \text { 1PL.EXCL.SBJ } & \text { also hoe eat-1PL.EXCL.SBJ.PFV } \\ \text { gì gàáfá } & \text { mà-bàbá } \\ \text { with hoe } & \text { PL-father }\end{array}$

'We also hoe in order to eat, with a hoe like our fathers.'

b. wayu ho a-tot-ni sum-te fox come PURP-take-3MSG.SBJ.PFV meat-the 'The fox came in order to take the meat.'

Note further in (a) above that the prepositional phrase follows the finite verb though it modifies the converb. This confirms that the converb and finite verb consitute a tight syntactic structure. In example (66), however, the converb and finite verb are separated by a subject noun. 
(66) gìtà hó ̀̀̀ ' fá-ná-fàá

when come pig eat-3MSG.SBJ.PFV-RED

kàp-mì Jín à mà

take-1PL.EXCL.SBJ.PFV spear GEN 1PL.EXCL.POSS

'When a pig comes to eat (lit. comes and eats), we take our spear.'

Further research is needed to see whether there are any restrictions on what may separate the converb(s) and finite verb.

(b) Coextensive converbs. There is also a second situation in which converbs are used, one which does not fall into the category described by Zelealem (2005:31) as one action preceding another action. Hetzron uses the term "coextensive" to refer to a group of functions for such converbs.

One coextensive function is a converb that is "governed" by the lexical nature of the finite verb. This is the case in example (67) with 'begin to wear' (lit. 'begin and wear') in (a) and 'eat completely' (lit. 'eat and finish') in (b). These may have become idiomatic expressions.
a. ina
sú-sú
wé-bí
ว่́yó

mothers begin-RED wear-3PL.SBJ.PFV clothes

'Mothers began to wear clothes (lit. Mothers began and wear clothes).'

$\begin{array}{llll}\text { b. gí Jín-kó } & \text { s'í gìdè fá } & \text { k’ú-ní } & \text { sàmún } \\ \text { in past-ADV } & \text { rat when eat } & \text { finish-3MSG.SBJ.PFV corn }\end{array}$

'In the past, when rats ate all the corn (lit. ate and finished the corn)...'

In this case it is clear that the converb and finite verb do not indicate a series of actions in temporal sequence but one in which the two verbs refer to one united action.

Another non-sequential function of converbs is one where the actions described by the converb and the finite verb are actually meant to be understood as being

\footnotetext{
${ }^{9}$ This interpretation assumes that the verb is uninflected. Compare the form of the verb hój with the verb hi in the next example. This needs to be checked.
} 
simultaneous rather than sequential. This may be the case in example (68) with the verbs 'go' and 'look for.'

(68) má

gwàmá gídà hò̀̀-mì

k’á

1PL.EXCL.SBJ Gwama when go-1PL.EXCL.SBJ.PFV to

tòp tám-í hò Jáá-mà swáyá

drink honey-REL go look.for-1PL.EXCL.SBJ.PFV tree

'We Gwama, when we go to collect honey, we go and look for a tree (or: we go while looking for a tree?).'

Unfortunately, this example is ambiguous whether the converb h' 'go' refers to the action of leaving or of walking along. The same is true in the following example which can be interpreted as being either sequential or simultaneous.

máyò hò kès-bá idágà gwàmá

Bertha come enter-3PL.SBJ.PFV among Gwama

'The Bertha came and entered (or: came while entering) among the Gwama.'

Less ambiguous examples need to be found to verify whether Gwama converbs can in fact be used for simultaneous actions.

(c) Converb-final constructions. Another exception to the rule stated in Zelealem (2005:31) quoted above (namely that converbs precede "main," or finite, verbs) concerns imperfective verbs. With such verbs, the order of the verbs is reversed. In example (70) the finite verb occurs first followed by the uninflected converb. Note that in both (a) and (b), the finite verb carries the pronominal prefix while the converb is uninflected. In (a) the finite verb is also marked with the imperfective aspect marker; in (b) this marker has possibly dropped following the pronoun má and might appear in slow speech. Both (a) and (b) are examples of consecutive converbs. 
(70) a. gídà ì̀sá-mà-ì̀s

when come.down-1PL.EXCL.SBJ.PFV-RED

á-mè-tótá

Jám Èdídíf

IPFV-1PL.EXCL.SBJ.IPFV-return look.for new

'When we have come down, we go back and look for a new (tree).'

b. gìdà má

mì-k’’̀p̀̀

t'wí bò

when 1PL.EXCL.SBJ 1PL.EXCL.SBJ.IPFV-cut widen hole

tàm í-yàs zé tàm-í á-mè-tópètóp c̀é

honey in-place be honey-REL IPFV-1PL.EXCL.SBJ.IPFV-take.out-RED

'When we cut and widen the honey hole in the place where the honey is, we take it out.'

Further data will be needed to verify whether the order finite verb followed by converb always appears with imperfective verbs, and whether this can happen with other verbs as well.

(d) Converbs with direct objects. An object noun phrase may either follow or precede the converb-finite verb construction, as shown in example (67). (The verb phrase is bolded and the object marked with brackets.)

\section{a. gèté hò Jám-ní}

[kùlfí]

when go look.for-3MSG.SBJ.PFV safety.pin

'When he goes to look for the safety pin,'

b. ìdóònó [kwòjí yỳá-té] hò síkín-bà tát bò there skin goat-the go lay-3PL.SBJ.PFV in hole 'There the goat skin they go and lay in the hole.'

In line with the standard SVO word order of the language, the post-verb phrase position may be considered the default position while the pre-verb phrase position is likely a focus position. 
(e) Non-converb constructions. Instead of a converb and a finite verb, a series of actions may also be expressed by means of separate clauses containing finite verbs. In this case, the actions appear to be less closely connected than the situations described above involving a converb. This also appears to be the standard format when the verbs have different objects as in example (72).

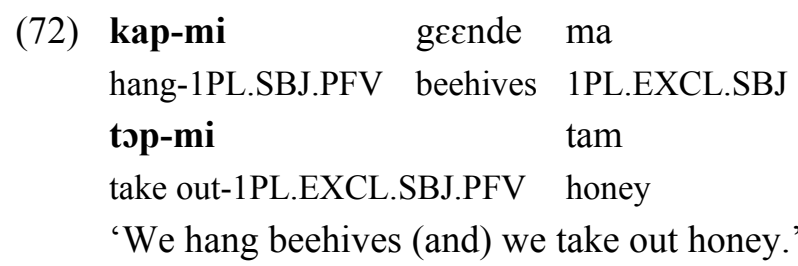

In all instances of converbs in the data, the subject of the converb and of the finite verb are identical. Further data will be needed to see whether converbs can also be used with different subjects.

The reason for choosing a finite verb versus a converb is not always obvious. In example (73), a finite verb is used initially where a converb might be expected.
a. tòd-ní
úg
tàm té-nà-té
take-3MSG.SBJ.PFV
container honey give-3MSG.SBJ.PFV-RED
'He takes a container of honey (and) he gives it to him.'

b. tò̀t-bé ḱ $\quad$ kwìf-bé-kwìfi
take-3PL.SBJ.PFV put skin-3PL.SBJ.PFV-RED
'They take (the tiger's body) and put it down and skin it.'

Further analysis on a discourse level will be needed to fully describe the conditions for casting a sentence in the form of a finite-finite or a converb-finite construction.

12.2 Auxiliary plus main verb. A second type of verb phrase, and one which in some ways resembles the converb-finite verb construction, involves the sequence of an auxiliary and a main verb. Like the converb-finite verb constructions discussed above, the auxiliary and main verbs also have the same subject. In this case, however, the first verb acts only as a carrier of grammatical information and has lost any 
lexical meaning it may have had before. Auxiliaries include the negative auxiliary and the verb $t i$.

(a) Negative verb. The negative construction consists of the negative verb followed by an uninflected main verb. It is illustrated in example (74). Note that the negative verb in this example is followed by two uninflected verbs. (The auxiliary and main verbs are marked by brackets and the negative auxiliary is bolded.)

(74)

$\begin{array}{llllll}\text { jyá } & \text { méntèć } & \text { gó } & \text { háy } & \text { gó } & \text { háy } \\ {\text { 3MSG.SBJ }{ }^{10}}^{\text {also }} & \text { and } & \text { 3MSG.SBJ } & \text { and } & \text { 3MSG.SBJ }\end{array}$

[dèc̀-bè tuta $\mathrm{s}^{\prime}$ it] bàrà-gàrà ${ }^{11}$ tánì pàn

NEG-3MSG.SBJ.NEG return have enmity other no

' $\mathrm{He}_{\mathrm{i}}$ also, he $\mathrm{i}_{\mathrm{i}}$ and he $\mathrm{ii}_{\mathrm{ii}}$ no longer have enmity (lit. $\mathrm{He}_{\mathrm{i}}$ also, he $\mathrm{e}_{\mathrm{i}}$ and he $\mathrm{i}_{\mathrm{ii}}$ does not return to have no other enmity).'

(b) $t i$ - verb. A second type of auxiliary is the verb ti (whose literal meaning is 'give'). In this case, too, the first verb is an inflected auxiliary while the second verb is an uninflected main verb. It is illustrated in example (75). Note that this auxiliary is used with an intransitive verb, 'dance,' in example (a), and with a transitive verb, 'dilute,' in (b).
a. àtà má
[tí-mà-gé
p'á]
then 1PL.EXCL.SBJ give-1PL.EXCL.SBJ.PFV-? dance
'Then we dance.'

b. ate pàyì-b ú- wí-tì
then dilute-3PL.SBJ.PFV SGV-beer-the
'Then they dilute the beer and drink.'

This auxiliary consists of the root $t i$ ' $g$ ive' followed by the subject suffix (which agrees with the subject of the main verb) and a final suffix $-g \varepsilon^{\prime}$, which remains

\footnotetext{
${ }^{10}$ The meaning of the word jyá is unclear. If it's an alternative form for the third person masculine singular, it is curious that in the same sentence the word háy is used.

${ }^{11}$ The word bàrà-gàrà is an Oromo loanword.
} 
constant. The suffix does not appear to be the -ga/-gi particle mentioned in Zelealem (2005:12), meaning past action, as it is used in texts describing habitual rather than past actions. It may, however, be a variant of the coordinating particle gi.

Note that the verb $t i$ may be used by itself as the main verb of a clause with the literal meaning 'give,' as in example (76). As seen in (a), even as the main verb it may contain the suffix -ge.

a. gidi halak-ni-ma $\mathrm{u}-\mathrm{y} \varepsilon \varepsilon \mathrm{r \varepsilon}$

when create-3MSG.SBJ.PFV-1PL.EXCL.OBJ.SGVSGV-God

tii-nI-ma-ge t'wa

give-3MSG.SBJ.PFV-1PL.EXCL.OBJ? language

mene uwe

1PL.INCL.POSS this

'When God created us, He gave us this our language.' 12

b. tí-mà pú dúf

give-1PL.EXCL.OBJ tied.cotton

'Give us tied cotton.'

While as an auxiliary the $t i$ verb carries grammatical information, other, discourserelated functions for the auxiliary are not ruled out. The auxiliary plus uninflected verb appears to be synonymous with the inflected finite verb, as shown in example (77). The clause in (a) appears to be synonymous with the adverbial clause in (b), which immediately follows it in the narrative.
a. tí-mà-gá
tòp' give-1PL.EXCL.SBJ.PFV-3MSG.OBJ drink
'We drink.'

b. tò̀'-mà

dònjí kwé-mà-kwé

doonò

drink-1PL.EXCL.SBJ.PFV after hoe-1PL.EXCL.SBJ.PFV-RED there

'After we drink, we hoe there.'

\footnotetext{
${ }^{12}$ The final part of the translation is tentative. It is not clear whether $u w e$ is a variant of $u t e$. In addition, the expected genitive marker $a$ is missing before the pronoun.
} 
One possibility is that the auxiliary actually has the meaning 'all' so that (a) could be translated as 'we all drink.'

Although the $t i$ construction also occurs in narratives from native Gwama speakers, it may be significant that it occurs most frequently in the Gwama texts produced by the speakers whose first language is Komo. Zelealem (2005) does not discuss this particular auxiliary.

\section{Noun phrases}

Noun phrases are head-initial. This section discusses the position of various modifiers.

The genitive construction consists of a head noun followed by a genitive marker and a possessive pronoun, noun, or noun phrase. This is illustrated in example (78). (The noun phrases are marked by brackets and the genitive construction is bolded.)

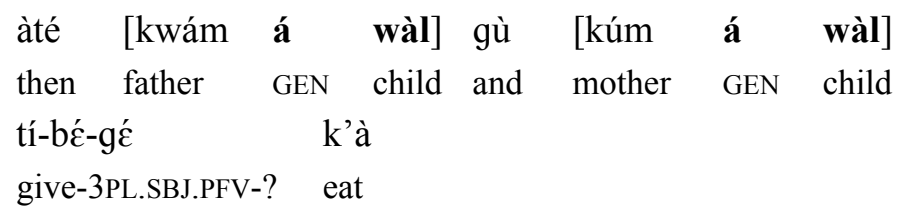

'Then the father of the child and the mother of the child eat.'

A noun may be modified by another noun without any derivational marking, as shown in example (79). Here again, the modifier wàp 'bride' follows the head noun fwi 'beer.'

(79) [ [wí wàp] kò-bá-kò

beer bride call-3PL.SBJ.PFV-RED

'They call it bride beer.'

This may be an example of what Zelealem (2005:29) calls a "source genitive" (such as 'cloth of cotton' and 'house of mud') which does not require an overt genitive marker. The meaning might then be that the beer was prepared by the bride (something that is not clear from the text itself). 
If both an adjective and a numeral occur, the numeral follows the adjective, as illustrated in example (80). Further data with numbers above 'one' is needed to substantiate this conclusion.

$\begin{array}{lllllll}\text { ù-sìt } & \text { àsććnè } & \text { kwá-ní } & \text { húnù } & {[\text { ù-śt }} & \text { gàátá } & \text { séćnè }] \\ \text { SGV-person } & \text { one } & \text { do-3MSG.SBJ-PFV } & \text { sick } & \text { SGV-person } & \text { old } & \text { one }\end{array}$

'if a person-one old person—gets sick'

Note that the numeral follows a modifying noun, just as it follows an adjective, as shown in example (81). In the two noun phrases (marked with brackets), the numeral sćénć 'one' (bolded) follows the modifying noun kikizà 'male person' and kíkíyátà 'female person.'

\begin{tabular}{|c|c|c|c|c|}
\hline -ní-s'ít & & à-té & [wál & kí-kí-zà \\
\hline V-3MSG. & SBJ.IPFV-catch & PURP-give & child & CLF-person-male \\
\hline & [wàl kí-kí-yát & & ććnć] & \\
\hline and & child CLF-pers & on-female & he & \\
\hline
\end{tabular}

'They catch in order to give one boy and one girl (lit. He catches to give one male child and one female child). ${ }^{, 13}$

The head noun may also be modified by a verb or relative clause, as illustrated in example (82). Note that the relative clause (bolded) follows the genitive construction in the noun phrase (marked with brackets). (The relative clause also contains a genitive construction.)

$$
\begin{array}{llll}
\text { àtà } & \text { má } & \text { tí-mà-gé } & \text { p'á } \\
\text { then } & \text { 1PL.EXCL.SBJ } & \text { give-1PL.EXCL.SBJ.PFV-? } & \text { dance }
\end{array}
$$

[ú-díin á mà Já k’úún s'íyàn á má]

SGV-enemy GEN 1PL.EXCL.POSSeat finish grain GEN 1PL.EXCL.POSS

'Then we dance (because of) our enemy, who ate and finished our grain.'

\footnotetext{
${ }^{13}$ People in the past had to give a male and female child to the local chief as tax for living on his land.
} 
The demonstrative pronoun or clitic occurs at the end of the noun phrase, as shown in example (83). Here the demonstrative pronoun àté follows the numeral.
a. gide má-k’à [mán swúya àté] when PST-eat children two those.F 'when those two children have eaten'
b. ìdóònó [kwòjí yỳá-àté $]$ hò síkín-bà tát bò there skin goat-this go lay-3PL.SBJ.PFV in hole 'There this goat skin they go and lay in the hole.'

\section{Main clauses}

14.1 Word order. Word order in Gwama is flexible. However, most often the object follows the verb as in (84).
dàz-bí
dà?
grind-3PL.SBJ.PFV butter
'They grind butter.'

With an overt subject pronoun or noun phrase, the standard word order is SVO, as in example (85).
[u-kalawandi $\mathrm{s}$ [ [k’we ko-ni $\mathrm{V}$ ]
[boo]
SGV-squirrel makes dig-3MSG.SBJ.PFV hole
'The squirrel dug a hole.'

Order is flexible, however, as seen in example (86), where the constituent order is SOV.
(86) [gàyá $\mathrm{S}$ [ábùm $\mathrm{O}$ ] [s'ìt-à k'á-k’á $\mathrm{V}$ ]
Oromo 2PL.OBJ catch-? eat-RED
'Oromo will catch you and eat you.' 
It is also possible to bring the object into focus by having it switch places with the subject, as shown in example (87). The word order of this clause is OVS.

[i-bírò ${ }_{\mathrm{O}} \quad$ [dá-bùn $\quad$ è̀ $\left.{ }_{\mathrm{V}}\right]$ [má-bàába $\left.\mathrm{S}_{\mathrm{S}}\right]$ Jin-ko

FOC-office NEG-3PL.SBJ.NEG know PL-father past-ADV

'Our fathers did not know offices in the past (lit. Offices they did not know our fathers in the past).'

14.2 Locative obliques. Sometimes the exact relationship of a noun and a verb can be determined only from context, as is the case in the clauses in example (88) (the locatives are bolded). Possibly, this applies only to physical locations.

a. ás'é zè-bí yàs

pay live-3PL.SBJ.PFV land

'They paid and lived on the land.'

b. gìdè pwò̀̀f-bá t'òòmó kò-bé gàbárà

when reach-3PL.SBJ.PFV house put-3PL.SBJ.PFV chair

'When they reach home they put it on a chair.'

14.3 Coordination. Two noun phrases may be coordinated with the particle gi (or its allomorph $g \grave{u}$ ) as in the clauses in (89).
a. tó-tót
kàp-ní
úg
[tam̀ ásèc̀n]
gì [nà] return-RED take-3Msc

'He returns and takes one container of honey and a goat.'

b. s'ít-ni

[kí-k-yáta

swíyá] ćc̀

have-3MSG.SBJ.PFV

CLF-person-female two

INTER

gí [màn kùbá-swíyá]

and children five-two

'He has two wives and seven children.' 


\section{Complex sentences}

15.1 Adverbial clauses. An adverbial clause is usually introduced with a temporal conjunction. The most common conjunction is gidè (or some variation of this, such as gìdà or git̀̇) 'when.' Contrary to the impression given in Zelealem (2005:25), the usual position of the conjunction is the beginning of the clause, as in (90). The conjunction is bolded and the adverbial clause marked with brackets.

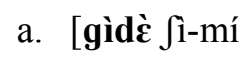
gàyá]
mí-gù-gùs
when see-2PL.SBJ.PFV Oromo IMP.PL-run-RED
'When you (PL) see Oromos, run (away)!'

b. [gide ís sàmún òbù màá] when ripe corn village 1PL.EXCL.POSS púnt'-má kò-kò-má swúy é-lògún cut-1PL.EXCL.SBJ.PFVput-RED-1PL.EXCL.SBJ.PFV house on-wall 'When the corn is ripe in our village, we cut it and put it in (our) house on the wall.'

The adverbial conjunction also appears in non-initial position, as shown in (91). Note that in this position it may be preceded not only by the subject in (a) (as noted in Zelealem 2005:25), but also by the object in (b). Furthermore, in (a) it is also preceded by an adverbial phrase.

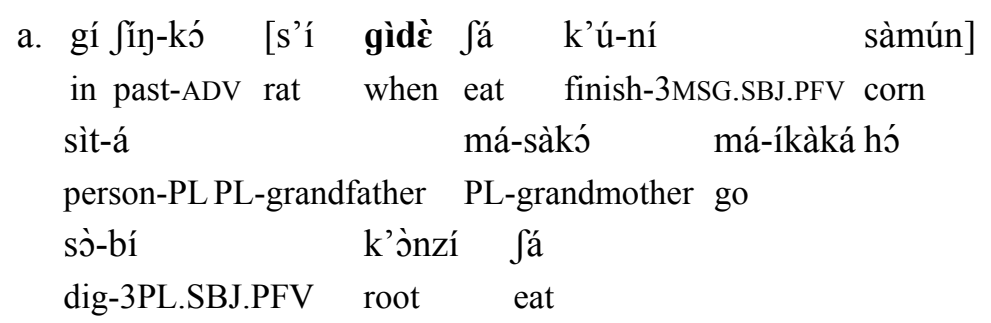

'In the past, when rats ate all the corn, people-(our) grandfathers and grandmothers-went and dug (bamboo) root and ate it.' 
b. [ùùzéć gìdè k'úf-bè-k'úf] á-bé-tẃ animals when kill-3PL.SBJ.PFV-RED IPFV-1PL.SBJ.IPFV-call sít'-a be-tòòtítòò-tò person-PL 3PL.SBJ.IPFV-take-RED ${ }^{14}$

'When they kill animals, they call people to take (the animals).'

Example (92) shows another conjunction, bilḱ, also translated 'when,' in second position. $^{15}$

(92) má gwàmá bílé zè̀̀-má

1PL.EXCL.SBJ Gwama when live-1PL.EXCL.SBJ.PFV

tát wàwàn $\tilde{\varepsilon} y \tilde{\varepsilon}$ kwéć-me síyàná in grass hut cultivate-1PL.EXCL.SBJ.PFV grain

'We Gwama, when we lived in grass huts, we cultivated grain.'

The non-initial position for the conjunction is commonly employed in introductory statements of a text. The initial phrase introduces the topic of the story. Thus, rather than interpreting the conjunction as having moved, it is more appropriate to see the subject or object noun as having moved to the beginning of the clause, before the adverbial conjunction, in order to bring it into focus as the topic of the text.

Relative clauses often end with the relative marker $-i$. Compare the two clauses in example (93). The main clause is given in (a); the relative clause is given in the first part of (b). The two clauses are identical except for the relative marker at the end of the adverbial clause in (b).
a. ù-sćéné
bà-pí
búgúnè úp
SGV-one
circle-3PL.SBJ.PFV
around head
'They circle one (chicken) around the (person's) head.'

\footnotetext{
${ }^{14}$ An imperfective prefix $a$ - would be expected on this verb. Likely, it has merged with the suffix $a$ - on the preceding noun.

${ }^{15}$ This conjunction may refer to a more remote past. It is used by the same speaker who uses gidè elsewhere (even in the same text), which does not rule out the possibility of its being a synonym or a borrowed word.
} 

b. gìdè bà-pí búgúnè úp-í
when circle-3PL.SBJ.PFV aroundhead-REL
ù-śćn $\quad \int \grave{\varepsilon}-b \dot{\varepsilon}-\int \grave{\varepsilon}$
SGV-one slaughter-3PL.SBJ.PFV-RED

'When they circle one (chicken) around the (person's) head, they slaughter the other one.'

From a discourse perspective, the example above also demonstrates the use that is made of adverbial clauses in narratives. Often the information is presented first by way of a main clause and then repeated in the form of an adverbial clause, as a means of creating text cohesion.

15.2 Adjectival clauses. Just like an adjective, an adjectival clause follows the noun it modifies, as in example (94). The adjectival clause has been marked with brackets.
$\begin{array}{lllllll}\text { a. átè } & \text { beteseb } & \text { sít-á } & {\left[\text { s'ít }^{\prime}\right.} & \text { gà } & \text { Bungul } & \text { Demis } \\ \text { those } & \text { relatives } & \text { person-PL } & \text { have } & 1 \text { SG.SBJ } & \text { Bungul } & \text { Demis }\end{array}$
gi ítùr késèrr]
in town Keser
'These relatives are the people that I, Bungul Demis, have in the town of Keser.'

b. tútú kútóbóó s’é yàgàs sććnò swáyá sc̀cne return cut ear leaf one tree one [púyúf kò-pá-k̀̀] tree.SP call-3PL.SBJ.PFV-RED

'They return and cut one leaf of a tree they call the puyush tree.'

Note in (a) above that rather than an inflected verb, we find an uninflected verb followed by the free pronoun (c.f. example (52) above). In (b) the object precedes the verb. Both of these features may be specific to adjectival clauses. This will need to be checked against additional data. 


\section{Abbreviations}

$\begin{array}{llll}? & \text { Meaning unknown/uncertain } & \text { M } & \text { Masculine } \\ 1 & \text { first person } & \text { NEG } & \text { Negative } \\ 2 & \text { second person } & \text { OBJ } & \text { Object } \\ 3 & \text { third person } & \text { PASS } & \text { Passive } \\ \text { ACC } & \text { Accusative } & \text { PFV } & \text { Perfective } \\ \text { ADV } & \text { Adverb } & \text { PL } & \text { Plural } \\ \text { CLF } & \text { Classifier } & \text { POSS } & \text { Possessive } \\ \text { DAT } & \text { Dative } & \text { PST } & \text { Past } \\ \text { EXCL } & \text { Exclusive } & \text { PURP } & \text { Purposive } \\ \text { F } & \text { Feminine } & \text { RED } & \text { Reduplication } \\ \text { FOC } & \text { Focus } & \text { REL } & \text { Relativizer } \\ \text { GEN } & \text { Genitive } & \text { SBJ } & \text { Subject } \\ \text { IMP } & \text { Imperative } & \text { SC } & \text { Subject Complement } \\ \text { INCL } & \text { Inclusive } & \text { SG } & \text { Singular } \\ \text { INTER } & \text { Interjection } & \text { SGV } & \text { Singulative } \\ \text { IPFV } & \text { Imperfective } & & \end{array}$

\section{Appendix: Texts}

(1) Hunting wild pigs

1. má gwàmá bílé zè̀̀-má tát wàwàn $\tilde{\varepsilon} y \tilde{\varepsilon}$ 1PL.EXCL.SBJ Gwama when live-1PL.EXCL.SBJ.PFV in grass hut kwéź-me síyàná

cultivate-1PL.EXCL.SBJ.PFV grain

'When we Gwama lived in grass huts, we cultivated grain.' 
2. gìtà hój̀ wàp'

Já-ná-fàá kàp-mì

when come pig eat-3MSG.SBJ.PFV-RED take-1PL.EXCL.SBJ.PFV

fín à mà

spear GEN 1PL.EXCL.POSS

'When a pig comes and eats, we take our spear.'

3. tí-mágá t’ój̀ỳ̀ één súgúm

creep-1PL.EXCL.SBJ.PFV? slowly at night

'We creep slowly at night.'

4. gìtà kààm-ź-kààm méć

When find-1PL.EXCL.SBJ.PFV-RED 1PL.EXCL.SBJ

s̀̀-mé-sò

spear-1PL.EXCL.SBJ.PFV-RED

'When we find (it, i.e., the pig) we spear (it).'

5. gìdà gùs-ní-gùs-ií gí ót-kó

When run-3MSG.SBJ.PFV-RED-REL in morning-ADV

à-nà-twí mánì gwà à nà

IPFV-1SG.SBJ.IPFV-call children brother GEN 1SG.POSS

táb-ájí ú-wàp

follow-1PL.EXCL.SBJ.PFV see SGV-pig

'When it runs, in the morning, I call my brothers and we follow the pig and see it.'

6. só-ní-gé gì sùgùn

spear-1SG.SBJ.PFV-3MSG.OBJ at night

'I spear it at night.' 
7. gìtè ùù táp-mè-táp ćn zì̀rí

when ? follow-1PL.EXCL.SBJ.PFV-RED in morning

tàb-à kófí-mè-kófí

follow-1PL.EXCL.SBJ.PFV kill-1PL.EXCL.SBJ.PFV-RED

p'á-mè-p'á

dance-1PL.EXCL.SBJ.PFV-RED

'When we track it in the morning, we follow and kill it and

we dance.'

8. gìdè p’á-mè-p’á á-mè-yìyìs

when dance-1PL.EXCL.SBJ.PFV-RED IPFV-1PL.EXCL.SBJ.IPFV-circle

t’wà zìzííí

mouth fence

'When we dance, we circle around the compound fence.'

9. úp $\dot{\varepsilon}$ dé tòtó kò-mé t’wà zìzí́ní

head GEN 3MSG.POSS bring put-1PL.EXCL.SBJ.PFV mouth fence

'We bring its head and put it on the compound fence.'

10. àtà má

tí-mà-gé

p’á ú-díìn

then 1PL.EXCL.SBJ give-1PL.EXCL.SBJ.PFV-? dance SGV-enemy

á mà Já k'úún s'íyàn á má

GEN 1PL.EXCL.POSSeat finish grain GEN 1PL.EXCL.POSS

'Then we dance because of our enemy who ate and finished our grain.'

11. àtè gélè mìnà gí tà-mà mà-báàbá

that ? ? work leave.behind-1PL.EXCL.OBJ PL-father

àtè gélè

that ?

'That is the work our fathers left behind for us.' 
(2) Collecting wild honey

1. má gwàmá gídà hòj-mì k’áj

1PL.EXCL.SBJ Gwama when go-1PL.EXCL.SBJ.PFV to tòp tám-í hò Jáá-mà swáyá

drink honey-REL go look.for-1PL.EXCL.SBJ.PFV tree

'We Gwama, when we go to collect honey, we go and look for a tree.'

2. i-zíy $\quad$ $\quad$ máá wí-màà wús swáyá PL-eye GEN 1PLPOSS look-1PL.EXCL.SBJ.PFV up tree

'We look at the tree (lit. Our eyes we look up the tree).'

3. gídà kàm-é kúm tàm-í twí-nó

when find-1PL.EXCL.SBJ.PFV bees honey-REL call-1SG.SBJ.PFV

wàl-kwá wè-yá-wè hò-nì tóp tàm

child-father friend ? come-IMP take honey

'When we find honey bees, I call my brother, 'Friend, come and take honey.'

4. átè mì-sélé wússí́

then 1PL.EXCL.SBJ.IPFV-climb up

'Then we climb up.'

5. à-mè-kú @ gí ànt

IPFV-1PL.EXCL.SBJ.IPFV-blow.smoke with fire

'We blow smoke with fire.'

6. wàl-kwám á nà á-ní-fí-fí sćl

child-father GEN 1SG.POSS IPFV-3MSG.SBJ.IPFV-hold-RED climb?

gí gì úúgú gi pans'

with ? gourd and axe

'Then my brother holds the gourd and climbs the tree with the gourd and the axe.' 
7. á-ṁ̀-gó k'òópó

IPFV-1PL.EXCL.SBJ.IPFV-cut cut

'We cut.'

8. gìdà má mè-k'j̀pè t'wí bò tàm

when 1PL.EXCL.SBJ 1PL.EXCL.SBJ.IPFV-cut widen hole honey

í-yàs ż́ tàm-í á-mè-tópètóp żé

in-place be honey-REL IPFV-1PL.EXCL.SBJ.IPFV-take.out-RED

'When we cut to widen the honey hole in the place where the honey is, we take it out.'

9. wàl-kwám á ná á-ná-kì úne úúgú child-father GEN 1SG.POSS IPFV-3MSG.SBJ.IPFV-put into gourd 'My brother puts it into the gourd.'

10. áté míné gîi zè mà gwàmá-tè that ? work be 1PL.EXCL.SBJ Gwama-the 'That is the work we Gwama do.'

11. gídà ì̀sá-mà-ì̀s

when come.down-1PL.EXCL.SBJ.PFV-RED

á-mè-tótá Jám èdídíj

IPFV-1PL.EXCL.SBJ.IPFV-return look.for new

'When we have come down, we return and look for a new (tree).'

12. gida ií úúg á màá á-mè-tútá when fill gourd GEN 1PL.EXCL.POSS IPFV-1PL.EXCL.SBJ.IPFV-return hò pwàn bwá go road home

'When we fill our gourd, we go home.' 


\section{References}

Ahland, Colleen. 2010. The classification of Gumuz and Koman languages. Paper presented at the Workshop on African Isolates. Lyon, France, Universite Lumiere, Dec. 3-4, 2010. Manuscript.

Amha, Azeb and Gerrit Dimmendaal. 2006. The converb in an African perspective. In Ameka, Felix, Alan Dench and Nicholas Evans (eds.), Catching Language: The Standing Challenge of Grammar Writing, pp. 393-440. Berlin: Mouton de Gruyter.

Bender, M. Lionel. 1983. Proto-Koman phonology and lexicon. Afrika und Übersee 66: 259-297.

Bender, M. Lionel. 2007. Koman. In Siegbert Uhlig (ed.), Encyclopaedia Aethiopica 3:416-418. Wiesbaden: Harrassowitz Verlag.

Burns, Samuel J. 1947. Notes towards a grammar of the Koma language. London: Sudan Interior Mission.

Greenberg, Joseph. 1990. Nilo-Saharan moveable k- as a stage III article (with a Penutian typological parallel). In Keith Denning and Suzanne Kemmer (eds.), On language: Selected writings of Joseph H. Greenberg. Stanford, CA: Stanford University Press.

Hellenthal, Anne-Christie. n.d. Notes on Mao. SIL Ethiopia. Unpublished ms.

Hellenthal, Anne-Christie and Constance Kutsch Lojenga. 2011. Phonology / Orthography statement for the Gwama language Ttwa Gwama spoken in the Benishangul-Gumuz region, Ethiopia. SIL Ethiopia. Unpublished ms.

Lewis, M. Paul, ed. 2009. Ethnologue: Languages of the world. Sixteenth edition. Dallas, TX: SIL International. Online version: http://www.ethnologue.com/.

Siebert, Ralph and Michael Bryant. 2007. Kwama. In Siegbert Uhlig (ed.), Encyclopaedia Aethiopica Vol 2. Wiesbaden: Harrassowitz Verlag.

Siebert, Ralph, Kati Siebert, and Klaus Wedekind. 2002. Sociolinguistic survey report on languages of the Asosa, Begi, Komosha area: Part I. SIL Electronic Survey Reports 2002-054. Available online at: http://www.sil.org/silesr/2002/SILESR2002-054.pdf (accessed 3/12/11). 
Wedekind, Klaus and Charlotte Wedekind. 2002. Sociolinguistic survey report on languages of the Asosa, Begi, Komosha area: Part II. SIL Electronic Survey Reports 2002-055. Available online at: http://www.sil.org/silesr/2002/SILESR2002-055.pdf (accessed 3/12/11).

Zelealem Leyew. 2005. Gwama: A little-known endangered language of Ethiopia: A sketch of its grammar and lexicon. Addis Ababa: Addis Ababa University. Available online at: http://www.uni-koeln.de/gbs/images/guama.pdf (accessed 3/12/11).

DirkKievit

SIL Ethiopia

dirk_kievit@sil.org

Erika Robertson

SIL Ethiopia

erika_robertson@sil.org
Accepted: 15 July 2012

Revisions: 5 September 2012 